Article

\title{
Development of Self-Assembled Nanoribbon Bound Peptide-Polyaniline Composite Scaffolds and Their Interactions with Neural Cortical Cells
}

\author{
Andrew M. Smith, Harrison T. Pajovich and Ipsita A. Banerjee * \\ Department of Chemistry, Fordham University, 441 East Fordham Road, Bronx, New York, NY 10458, USA; \\ asmith169@fordham.edu (A.M.S.); hpajovich@fordham.edu (H.T.P.) \\ * Correspondence: banerjee@fordham.edu; Tel.: +1-718-817-4445 \\ Academic Editor: Gary Chinga Carrasco \\ Received: 4 November 2017; Accepted: 8 January 2018; Published: 13 January 2018
}

\begin{abstract}
Degenerative neurological disorders and traumatic brain injuries cause significant damage to quality of life and often impact survival. As a result, novel treatments are necessary that can allow for the regeneration of neural tissue. In this work, a new biomimetic scaffold was designed with potential for applications in neural tissue regeneration. To develop the scaffold, we first prepared a new bolaamphiphile that was capable of undergoing self-assembly into nanoribbons at $\mathrm{pH}$. Those nanoribbons were then utilized as templates for conjugation with specific proteins known to play a critical role in neural tissue growth. The template (Ile-TMG-Ile) was prepared by conjugating tetramethyleneglutaric acid with isoleucine and the ability of the bolaamphiphile to self-assemble was probed at a $\mathrm{pH}$ range of 4 through 9 . The nanoribbons formed under neutral conditions were then functionalized step-wise with the basement membrane protein laminin, the neurotropic factor artemin and Type IV collagen. The conductive polymer polyaniline (PANI) was then incorporated through electrostatic and $\pi-\pi$ stacking interactions to the scaffold to impart electrical properties. Distinct morphology changes were observed upon conjugation with each layer, which was also accompanied by an increase in Young's Modulus as well as surface roughness. The Young's Modulus of the dried PANI-bound biocomposite scaffolds was found to be $5.5 \mathrm{GPa}$, indicating the mechanical strength of the scaffold. Thermal phase changes studied indicated broad endothermic peaks upon incorporation of the proteins which were diminished upon binding with PANI. The scaffolds also exhibited in vitro biodegradable behavior over a period of three weeks. Furthermore, we observed cell proliferation and short neurite outgrowths in the presence of rat neural cortical cells, confirming that the scaffolds may be applicable in neural tissue regeneration. The electrochemical properties of the scaffolds were also studied by generating I-V curves by conducting cyclic voltammetry. Thus, we have developed a new biomimetic composite scaffold that may have potential applications in neural tissue regeneration.
\end{abstract}

Keywords: self-assembly; templates; tissue regeneration; peptide amphiphiles

\section{Introduction}

The nervous system consists of a network of interconnected cells that play a critical role in the reception and transmission of electrical signals throughout the body [1,2]. However, damage to the nervous system caused by brain injuries or neurodegenerative disorders such as, Alzheimer's, Parkinson's, epilepsy, multiple sclerosis, or chronic traumatic encephalopathy, can lead to severe impairment in daily function and quality of life [3,4]. The slow growth and fragility of nervous tissue poses a unique challenge for treatment interventions. Current treatments are limited to nerve autographing and the use of nerve conduits [5], as well as development of novel antagonists [6]. These 
methods are challenged by the lack of donors, tissue rejection, scar tissue growth, implantation decay and lack of sufficient structural and biochemical information at the biomolecular level [7]. Tissue Engineering (TE) poses an alternative treatment option to conventional methods. TE seeks to repair, restore and replace damaged tissues and harbor growth of healthy tissue [8]. This is accomplished by creating a biomimetic three-dimensional matrix that exemplifies properties of the extracellular matrix (ECM), which can eventually aid in re-growing tissue [9]. These scaffolds are tailored to specific tissues to ensure compatibility and alleviate immune response and scar tissue growth and support new tissue by proper adhesion and integration $[10,11]$.

Since the inception of TE, a multitude of materials, both natural and synthetic, have been discovered to promote neural tissue growth [12]. For example, functionalized carbon nanotubes and graphene nanotubes have been successful in promoting cell differentiation and migration, while efficiently maintaining conductive properties within the tissue [13-15]. Polymers [16] such as polyethylene glycol (PEG), poly $\varepsilon$-caprolactone (PCL), poly(lactic-co-glycolic acid) (PLGA) and poly-lactic acid (PLA) are some of the most widely used synthetic polymers [17]. Specifically, they have been used to create neural guidance conduits and cylindrical porous electrospun composites to promote axonal growth and to bridge neural ending defects [18]. For instance, it was reported that composites of poly $\varepsilon$-caprolactone electrospun membranes and gelatin improved cell adhesion, proliferation and differentiation of PC-12 nerve cells and supported neurite outgrowth [19]. In a recent study, it was shown that irradiation of graphitic carbon nitride integrated with graphene oxide (GO) that was bound to electrospun PCL/gelatin fibers resulted in neural stimulation upon irradiation with visible-light and thereby supported neuronal differentiation [20]. Amongst the naturally occurring proteoglycans, hyaluronic acid, chitosan, chondrotin sulfate and heparin sulfate have gained significant prominence [21] in the preparation of composite materials for neural TE. For example, in one study, chondroitin-6-sulfate and neural growth factor (NGF) were fused into PEG gels and promoted neurite extension and viability of cortical cells $[22,23]$. In a separate study, heparin-mimicking polymers-prepared by combining glucosamine-like 2-methacrylamido glucopyranose monomers with three separate sulfonated units-showed higher cytocompatibility and promoted differentiation of embryonic stem cells to neuronal cells as compared to natural heparin [24]. Forsythe and co-workers developed three-dimensional graphene-heparin-poly-L-lysine polyelectrolytes that promoted neuron cell adhesion, proliferation and neurite outgrowth [25]. It has also been shown that hyaluronic acid bound electrospun PCL scaffolds as well as agarose-chitosan blends enhance mechanical properties and increased proliferation of neural cells $[26,27]$.

In addition to the aforementioned biomaterials, peptide amphiphiles have gained prominence in numerous biomedical applications due to their facile self-assembling properties, biocompatibility and relative ease of functionalization [28]. For example, when peptide nanofibers formed by self-assembly of amphiphilic (palmitoyl-GGGAAAKRK) were utilized for siRNA delivery into the brain, they showed higher intra-cellular uptake after being delivered intra-cranially [29]. Stupp and co-workers recently showed that hybrid DNA-peptide nanotubes that had been prepared by altering the sequence of the DNA strands and incorporating the cell-adhesion motif RGDS displayed selectivity and enhanced cell adhesion and differentiation of neural stem cells into neurons but not astrocytes [30]. Scaffolds formed by utilizing the self-assembling peptide RADA16-I have demonstrated potential in closing neural gaps and regenerating axons and healing spinal cord injuries [31]. Researchers have also developed hybrid matrices by combining Type I collagen and peptide amphiphile based nanofibrous scaffolds functionalized with IKVAV or YIGSR that showed specific responses to cerebellar cortex Granule cells and Purkinje cells. Specifically, the IKVAV hybrid scaffolds showed an increase in granule cell density and growth of Purkinje cell dendrite and axons in the presence of peptide nanofibers over specific concentration ranges compared to collagen [32].

In this work, we have developed a new biomimetic scaffold with potential for neural tissue engineering. We conjugated 3,3-tetramethylene glutaric acid (TMG) with isoleucine (Ile) to form a new bolaamphiphile, wherein TMG was the inner head group while the two isoleucine groups formed 
the tail groups at each end. The self-assembling ability of the Ile-TMG-Ile conjugate was probed at a $\mathrm{pH}$ range of 4-9. We observed that under neutral conditions, the conjugate self-assembled into nanoribbons, which were then utilized as templates for developing the scaffold. TMG has been shown to be biocompatible and is a well-known aldose-reductase inhibitor in vitro. It was once touted for its potential in inhibiting diabetic angiopathy and cataract formation by preventing the formation of sorbitol [33]. However, it was found to be relatively inactive as an aldose-reductase inhibitor in vivo, as significant amounts of TMG were unable to reach the retina or lens. We utilized TMG due to its unique structure containing the glutaric acid back bone functionalized with a cyclopentyl ring system. We conjugated it with isoleucine, as it is a key factor known to enhance the activity of alanine-serine-cysteine transporter (Asc-1), which mediates the release of Gly and Ser from neurons and modulates $N$-methyl-D-aspartate receptor (NMDAR) synaptic activity [34]. The nanoribbons formed upon self-assembly were utilized as templates for preparing tailored scaffolds for neural tissue regeneration. The template Ile-TMG-Ile nanoribbons were first conjugated with laminin, a major component of the extracellular matrix of vascular tissue in the brain. Laminin has been shown to increase the binding abilities of nanoscaffolds as well as to promote cell migration in newly formed cells $[35,36]$. A recent study conducted using a laminin functionalized PCl-chitosan scaffold showed increased mechanical properties, cell attachment and proliferation [37]. Another study found that laminin based scaffolds vastly improved neuronal survival in the injured brains of mice, which led to greater performance on spatial learning tasks [38].

We then conjugated the laminin bound assemblies with Artemin, which is a glial cell line derived neurotropic factor. Artemin is known to support signaling and increase growth in both peripheral and central nervous tissue by binding to GFR alpha3-RET, an artemin specific receptor in the MAP kinase pathway [39]. It has also been shown to attenuate neuropathic pain in individuals with spinal cord injuries and plays a protective role against deteriorating motor neurons in ALS patients [40,41]. To form the biocomposite, we then conjugated the laminin-artemin-bound templates with Type IV Collagen. It is well known that Type IV Collagen is a component of the basement membrane of vascular tissues in brain and forms mesh-like structures with advantageous mechanical properties. Furthermore, Type IV collagen promotes cell adhesion and stability [42].

Finally, emeraldine base polyaniline (PANI) — a conductive polymer-was incorporated to impart electric properties to the scaffold. PANI consists of repeat units of benzene rings which are separated by secondary amine groups and a quinoid ring system attached to imine groups [43]. The protonated form of emeraldine is conductive as it can form a semiquinone radical cation [44]. In a study where emeraldine polyaniline was blended with gelatin and then electrospun into nanofibers, the scaffold showed a marked increase in conductivity after incorporation of PANI [45]. Thus, we have created a new composite scaffold that consists of self-assembled nanoribbons, conjugated with key proteinaceous components to enhance growth and proliferation of neuronal cells as well as a conductive polymer, polyaniline to impart electrical properties. The formed scaffold demonstrated biodegradability, enhanced mechanical properties as well as promoted growth and proliferation of cortical cells and promoted axonal outgrowth Thus, these newly formed scaffolds may have potential applications in neural tissue engineering.

\section{Materials and Methods}

Amino acid isoleucine and 3,3-tetramethylene glutaric acid, dimethylformamide (DMF), $\mathrm{N}$-Hydroxy Succinimide (NHS), 1-ethyl-3-(3-dimethylaminopropyl) carbodiimide (EDAC) and triethylamine (TEA), Bradford reagent, Bovine serum albumin (BSA) were purchased from Sigma Aldrich. Buffer solutions of various $\mathrm{pH}$ values were purchased from Fisher Scientific. Mouse laminin (sc-29012) and laminin alpha-2 antibody (B-4) were purchased from Santa Cruz Biotechnology. NHS-rhodamine was purchased from Thermo Scientific. Anti-collagen Type IV (rabbit) antibody was purchased from Rockland. Human artemin (category 4515-20, lot P70215) was purchased from Bio Vision. Type IV collagen (AG 19502) was purchased from Neuromics. Rat cortical cells (E18) 
and cell culture media (NbActiv4) were purchased from BrainBits. Neuroblast cell culture media and Glutamax were purchased from Gibco. Polyaniline was purchased from Ark Pharmaceuticals. Solvent $N$-methyl-2-Pyrrolidine was purchased from VWR. The digital multimeter model M-1000D was purchased from Elenco and a $1.62 \mathrm{~mm}$ diameter platinum electrode was purchased from Bioanalytical Systems Incorporated.

\subsection{Synthesis of Ile-TMG-Ile}

To TMG (1M) were added NHS (0.1M) and EDAC (0.1M) in DMF for activating the carboxylic acid groups of TMG. The mixture was stirred for one hour at $4{ }^{\circ} \mathrm{C}$ followed by the addition of Ile (2M). Two drops of TEA were added and the reaction mixture was stirred at $4{ }^{\circ} \mathrm{C}$ for $24 \mathrm{~h}$. After $24 \mathrm{~h}$, the solution was rotary evaporated to remove the solvent. The product obtained was found to be a white solid. The ESI-MS obtained by HPLC-MS (Agilent 6100 series, Santa Clara, CA, USA) showed a very weak $\mathrm{M}+$ peak at $\mathrm{m} / \mathrm{z} 411.2$; peaks were also observed at $\mathrm{m} / \mathrm{z} 952.4$ and at $\mathrm{m} / \mathrm{z} 805.5$ due to the formation of oligmers. The strongest peak was seen at $\mathrm{m} / \mathrm{z} 393.2$ due to loss of hydroxyl radical. The product most likely undergoes McLafferty rearrangement, as expected for amides. Smaller fragments were observed at $\mathrm{m} / \mathrm{z}=360.2 ; 230.7,361.2$ and 115.0. Thus, in addition to Ile-TMG-Ile, side products that included oligomers were also formed. The product was recrystallized using methanol and dried under vacuum before further analysis. The yield of the product was found to $57.2 \%$. The formation of the product was confirmed by ${ }^{1} \mathrm{H}$ NMR spectroscopy using a Bruker $400 \mathrm{MHz}$ NMR (Billerica, MA, USA) in deuterated DMSO with TMS as a solvent. ${ }^{1} \mathrm{H}$ NMR (DMSO-d6) spectrum showed peaks at $\delta 0.9$ $(\mathrm{t}, 6 \mathrm{H}) ; \delta 1.2(\mathrm{~d}, 6 \mathrm{H}) ; \delta 1.4(\mathrm{t}, 2 \mathrm{H}) ; \delta 1.7(\mathrm{~m}, 4 \mathrm{H}) ; \delta 2.3(\mathrm{~d}, 2 \mathrm{H}) ; \delta 2.7(\mathrm{~s}, 4 \mathrm{H}) ; \delta 2.9(\mathrm{~s}, 4 \mathrm{H}) ; 3.4(\mathrm{~s}, 4 \mathrm{H}) ; \delta 8.1$ $(\mathrm{s}, 2 \mathrm{H}) ; \delta 12.2(\mathrm{~s}, 2 \mathrm{H}) .{ }^{13} \mathrm{C}$ NMR (DMSO-d6) showed peaks at $\delta 17.3 ; \delta 22.2 ; 25.3 ; \delta 29.6 ; \delta 33.4 ; \delta 39.5 \delta$ $42.7 ; \delta 45.9$ and $\delta 174.2$.

\subsection{Self-Assembly of Ile-TMG-Ile Template}

The synthesized product was allowed to self-assemble in buffer solutions of varying $\mathrm{pH}$ values. In general, the product $(45 \mathrm{mM})$ was allowed to assemble under acidic $(\mathrm{pH} 4$, potassium acid phthalate buffer); neutral ( $\mathrm{pH} 7$, potassium phosphate monobasic-sodium hydroxide buffer) and basic ( $\mathrm{pH} 9$, boric acid, potassium chloride, sodium hydroxide buffer) conditions over a period of three to four weeks at room temperature. The growth of assemblies was monitored by dynamic light scattering periodically. After four weeks of growth, the assemblies were centrifuged and washed thrice with deionized water to remove the buffer and left in deionized water for further analysis.

\subsection{Preparation of Scaffold}

The washed Ile-TMG-Ile assemblies grown at $\mathrm{pH} 7$ were utilized for preparation of scaffolds. An aqueous solution of the fibrillar assemblies $(2 \mathrm{mM})$ was treated with EDAC $(1 \mathrm{mM})$ and NHS $(1 \mathrm{mM})$ for one hour at $4{ }^{\circ} \mathrm{C}$ to activate the free carboxylic groups in Ile-TMG-Ile. Mouse laminin $(0.1 \mathrm{mg} / \mathrm{mL}, 200 \mu \mathrm{L})$ was then added to the activated template. The mixture was stirred at $4{ }^{\circ} \mathrm{C}$ for $24 \mathrm{~h}$ to allow for adhesion of laminin. The laminin bound templates were then washed and centrifuged thrice with deionized water to remove any unbound laminin followed by addition of EDAC $(1 \mathrm{mM})$ and NHS $(1 \mathrm{mM})$ for one hour at $4{ }^{\circ} \mathrm{C}$. To the laminin bound templates, artemin $(0.1 \mathrm{mg} / \mathrm{mL}, 200 \mu \mathrm{L})$ was then added and shaken at $4{ }^{\circ} \mathrm{C}$ for $24 \mathrm{~h}$ and washed and centrifuged thrice to remove unbound artemin. The laminin and artemin functionalized construct was once again allowed to react with EDAC $(1 \mathrm{mM})$ and NHS $(1 \mathrm{mM})$ for one hour at $4{ }^{\circ} \mathrm{C}$ followed by the addition of Type IV collagen $(0.1 \mathrm{mg} / \mathrm{mL}, 100 \mu \mathrm{L})$ and was shaken at $4{ }^{\circ} \mathrm{C}$ for $24 \mathrm{~h}$. The biocomposite was washed and centrifuged to remove unbound collagen. The formed biocomposite scaffold was then vacuum dried. To the dried scaffold, polyaniline (PANI) $(0.1 \mathrm{mg} / \mathrm{mL})$ in $N$-methyl-2-Pyrrolidine $(5 \mathrm{~mL})$ was added and the mixture was shaken at $4{ }^{\circ} \mathrm{C}$ for $24 \mathrm{~h}$ and then centrifuged for three hours to remove unbound PANI. 


\subsection{Binding Efficiency of Laminin, Artemin and Type IV Collagen on the Assemblies}

The efficiency of binding of each of the protein components was examined by UV-Vis spectroscopy which was monitored at $272 \mathrm{~nm}$ and the absorbance before and after binding to each of the proteins was measured. The absorbance of laminin $(0.1 \mathrm{mg} / \mathrm{mL}, 200 \mu \mathrm{L})$ was compared, with that of washed laminin bound assemblies which were prepared as described above. The volumes of the solutions were kept constant. Our results indicated $84.6 \%$ binding of laminin to the assemblies. Subsequently the protein concentration of laminin bound assemblies was determined using the Bradford method, based on a standard curve obtained for BSA $(1 \mathrm{mg} / \mathrm{mL})$. The concentration of laminin on the assemblies was found to be $2.5 \mu \mathrm{M}$. Similarly, upon binding with artemin, the binding efficiency was found to be $92.3 \%$ and the protein concentration was found to be $3.19 \mu \mathrm{M}$. Finally, for Type IV collagen, the binding efficiency was found to be $88.3 \%$ and the protein concentration after binding to Type IV Collagen was found to be $3.65 \mu \mathrm{M}$.

\subsection{In Vitro Biodegradability Studies}

To examine the biodegradability of the formed scaffold, $45 \mathrm{mg}$ of the scaffold was weighed in a petri dish to which $10 \mathrm{~mL}$ of simulated body fluid buffer (SBF) was added. The weight of the scaffold was measured every $10 \mathrm{~h}$ over a period of 22 days. In general, at each time point, the scaffold was rinsed with deionized water and air dried at room temperature before measurement of weight. The SBF was replaced as necessary each time with the same volume $(10 \mathrm{~mL})$. Studies were carried out in triplicate. The results were then analyzed as a function of time. The SBF was prepared according to previously established methods [46]. Briefly, to prepare the simulated body fluid (SBF) for biodegradability studies, $750 \mathrm{~mL}$ of distilled water was first brought to a constant temperature of $36.5^{\circ} \mathrm{C}$. The solution was constantly stirred while adding $7.996 \mathrm{~g}$ of $\mathrm{NaCl}, 0.350 \mathrm{~g} \mathrm{NaHCO}_{3}, 0.224 \mathrm{~g} \mathrm{KCl}, 0.228 \mathrm{~g} \mathrm{~K}_{2} \mathrm{HPO}_{4} 3 \mathrm{H}_{2} \mathrm{O}$,

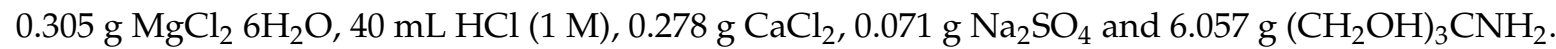
The $\mathrm{pH}$ was adjusted to 7.4 with dropwise addition of $1 \mathrm{M} \mathrm{HCl}$. The total volume was then brought to $1 \mathrm{~L}$ using distilled water and then the solution was stored at $4{ }^{\circ} \mathrm{C}$ before use.

\subsection{Cell Studies}

To examine cell viability, rat cortical cells (E18, lot, BrainBits) were cultured in NbActiv4 media (BrainBits) containing 1\% 10,000 g/mL amphotericin and 100 units/mL penicillin and streptomycin. The cells were grown to confluence and kept in a humidified atmosphere of $5 \% \mathrm{CO}_{2}$ at $37{ }^{\circ} \mathrm{C}$. To examine the effects of the scaffold, cells were plated in 12-well Falcon polystyrene tissue culture plates at a density of $1 \times 10^{3}$ cells per well. After allowing the cells to adhere to the well plates for two hours, scaffolds were added at varying concentration $(6 \mu \mathrm{M}, 10 \mu \mathrm{M}$ and $13 \mu \mathrm{M})$. The scaffolds were allowed to interact with the cells for 24,48 and $72 \mathrm{~h}$. These studies were carried out in triplicate. After each allotted period of time, cell viability and growth was examined by via trypan blue method. Cortical cells in media alone were used as a control for this study. Once stained with trypan blue, live and dead cells were counted using a hemocytometer and averaged. The percent viability was then calculated as follows: (living cortical cells)/(living cortical cells + dead cortical cells) $\times 100$. To observe the interactions of the cortical cells with the scaffolds, cells were plated and allowed to interact with scaffolds as before. The media was changed every $48 \mathrm{~h}$. Images were taken using an AmScope IN200TA-P Inverted Tissue Culture Microscope (Irvine, CA, USA) with a USB camera at various magnifications every $24 \mathrm{~h}$ over a period of seven days.

\subsection{Electrochemical Studies}

We first examined the resistance of control PANI, PANI-bound scaffolds and the biocomposite scaffold in the absence of PANI and determined the conductivity. The resistance of the scaffolds was tested in $\mathrm{HCl}(1 \mathrm{M})$. A digital multimeter, model M-1000D, from Elenco (Philadelphia, PA, USA) was then used to determine the resistance. To examine the electrochemical properties of the scaffold, we 
conducted cyclic voltammetry in the presence of PANI, PANI-bound scaffolds and the biocomposite scaffold before it was bound to PANI as control. To obtain I-V curves, the solutions were dried directly onto the $2.01 \mathrm{~mm}^{2}$ electrode using a vacuum pump for a period of $24 \mathrm{~h}$, adding an addition layer every $6 \mathrm{~h}$. A voltage cell was created using this working electrode, a platinum counter electrode, an $\mathrm{Ag} / \mathrm{AgCl}$ reference electrode and $1 \mathrm{M} \mathrm{HCl}$. Prior to electrochemical measurements, nitrogen was bubbled into the cell for $20 \mathrm{~min}$ to remove dissolved oxygen from the solution. PowerSuite by Princeton Applied Research and a Princeton Applied Research potentiostat model 263A (Oakridge, TN, USA) were used to obtain I-V curves from a potential of $-0.2 \mathrm{~V}$ to $0.9 \mathrm{~V}$ at $10 \mathrm{mV} / \mathrm{s}$.

\subsection{Characterization}

\subsubsection{Fourier Transform Infrared (FTIR) Spectroscopy}

FTIR spectroscopy was conducted using a Thermo Scientific Nicolet IS50 FTIR (Waltham, MA, USA) with OMNIC software. In general, samples were run at a range of $400 \mathrm{~cm}^{-1}$ to $4000 \mathrm{~cm}^{-1}$ with 100 scans per sample and the data obtained was averaged.

\subsubsection{Scanning Electron Microscopy (SEM)}

To examine the morphologies of the assemblies as well as the incorporation of each layer after conjugation, samples were air-dried on to carbon double stick tape and carbon coated to prevent charging. Samples were imaged at various magnifications between of $2 \mathrm{kV}$ to $10 \mathrm{kV}$ utilizing a Zeiss EVO MA10 scanning electron microscope (Thornwood, NY, USA).

\subsubsection{Transmission Electron Microscopy (TEM)}

In order to further elucidate the morphologies of the assemblies we also conducted TEM analysis using JEOL 1200 EX transmission electron microscope (Peabody, MA, USA). Samples were air-dried on to formvar/carbon 200 mesh copper grids overnight before analysis. Samples were imaged at various magnifications at $80 \mathrm{KeV}$.

\subsubsection{Dynamic Light Scattering (DLS)}

To monitor the growth of the assemblies, we conducted DLS using a NICOMP 380 ZLS sizer (Willow Grove, PA, USA). Samples were diluted to appropriate concentrations and each sample was run at least three times and the data obtained was averaged.

\subsubsection{Atomic Force Microscopy (AFM)}

We examined the nanoscale morphology of the assemblies after conjugation with each layer using a Bruker Multimode 8 AFM (Santa Barbara, CA, USA). Furthermore, the mechanical properties of the scaffolds were also determined by conducting Peak Force Microscopy. The tip was moved to various points (at least five points per sample) on each sample and the values obtained were averaged. Young's Modulus was determined by fitting the data into a Hertzian Model. In general, we used RTESPA-175 Antimony (n) doped Si tip with a spring constant of $40 \mathrm{~N} / \mathrm{m}$.

\subsubsection{Differential Scanning Calorimetry (DSC)}

To explore the thermal phase changes of the scaffolds, we conducted DSC analysis. For each analysis, $0.1 \mathrm{mg}$ samples were dried under vacuum and weighed. We examined the phase changes for each layer of the scaffold using a TA instruments, model Q200 instrument (New Castle, DE, USA) at a temperature range of $0{ }^{\circ} \mathrm{C}$ to $250{ }^{\circ} \mathrm{C}$ at scanning rate of $10^{\circ} \mathrm{C}$ per minute. 


\subsubsection{Fluorescence Microscopy}

Fluorescence microscopy was carried out to examine the interactions of FITC labeled laminin -2 antibody (B-4) with laminin bound assemblies and rhodamine labeled Type IV collagen with the biocomposites using a Phase Contrast Amscope Fluorescence Inverted Microscope (Irvine, CA, USA). To prepare samples for binding with laminin antibody, the laminin bound assemblies were washed and centrifuged with deionized water followed by the addition of BSA Blocker solution (1\% BSA) in tris buffered saline to prevent non-specific binding. The sample was vortexed for two minutes and allowed to incubate at room temperature for $4 \mathrm{~h}$. The sample was then centrifuged and washed once with TBS followed by washing with deionized water. To the sample, we then added FITC labeled laminin -2 antibody (B-4) $(50 \mu \mathrm{g} / \mathrm{mL})$. The sample was incubated overnight at $4{ }^{\circ} \mathrm{C}$. Samples were then washed and centrifuged with deionized water and imaged on poly-L-lysine coated glass slides which was covered by a coverslip. Samples were then excited at $450 \mathrm{~nm}$. A similar protocol was followed for examining the interactions of rhodamine labeled collagen IV antibody, where in the collagen IV-artemin-laminin-bound Ile-TMG-Ile assemblies were first washed and centrifuged, followed by the addition of $1 \%$ BSA blocking agent before incubation with the antibody. Finally samples were transferred to glass-slides covered with coverslips and imaged at $588 \mathrm{~nm}$ excitation.

\subsubsection{UV-Vis Spectroscopy}

To determine the binding efficiency and protein concentrations of the biocomposite assemblies after each layer of protein (laminin, artemin and Type IV collagen) was added, we carried out UV-Vis spectroscopy using a Nanodrop 2000 spectrophotometer (Waltham, MA, USA).

\subsection{Statistical Analysis}

We used two-tailed Student's t-test for carrying out statistical analysis. Studies were carried out in triplicate $(n=3)$. Data are presented as the mean value \pm standard deviation (SD) of each sample group.

\section{Results and Discussion}

\subsection{Self-Assembly of Ile-TMG-Ile}

Molecular self-assembly of biomolecules transpires through weak, non-covalent interactions that include electrostatic, hydrophobic interactions, hydrogen bonds, van der Waals interactions and $\pi-\pi$ stacking forces that result in the formation of stable and functional supramolecular structures [47]. Self-assembling peptides, in particular form unique supramolecular assemblies and offer several advantages. Thus, such materials pose a plethora of applications in tissue engineering as they are highly biocompatible and modifiable [48].

In this work, we designed a new bolaamphiphile by conjugating the amino acid Ile with the dicarboxylic acid 3,3 tetramethylene glutaric acid (TMG) resulting the in the formation of (2S,2'S,3S,3'S)-2,2'-((2,2'-(cyclopentane-1,1-diyl)bis(acetyl))bis(azanediyl))bis(3-methylpentanoic cid), abbreviated as Ile-TMG-Ile (Figure 1). In previous work, peptide based bolaamphiphiles containing amino acid moieties such as glycine, conjugated with dicarboxylic acids such as azelaic acid have been shown to self-assemble into nano and microtubes with closed ends or single layered sheets [49]. In an earlier study, we have shown that when phenylalanine was conjugated with dicarboxylic acids of different chain lengths, supramolecular assemblies of a variety of morphologies were formed depending upon the growth conditions used [50]. It has also been shown that peptide amphiphiles containing N-terminus palmitoylated groups such as $\mathrm{CH}_{3}-\left(\mathrm{CH}_{2}\right)_{14} \mathrm{CO}-\mathrm{NH}-\mathrm{X}-\mathrm{Ala}_{3}-\mathrm{Glu}_{4}-\mathrm{CO}-\mathrm{NH}_{2}$, where in the amino acid $\mathrm{X}$ was varied between Ile, Phe or Val, self-assembled into micelles, nanoribbons or nanofibers depending upon the $\mathrm{pH}$ of the growth conditions [51]. 

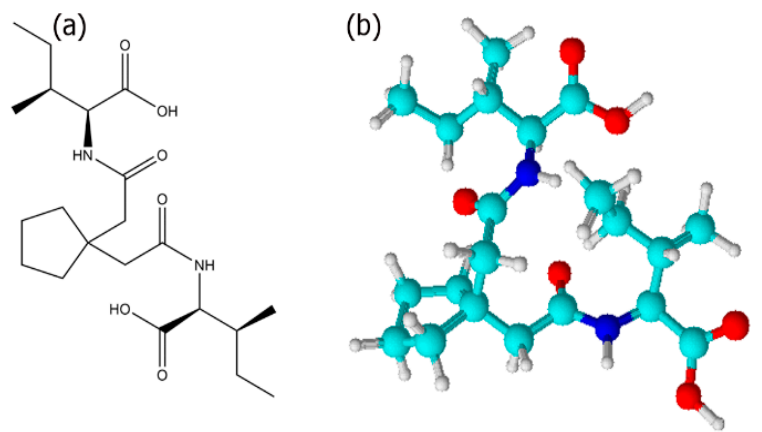

Figure 1. (a) Chemical structure of Ile-TMG-Ile; (b) ball and stick model.

Herein, we examined the self-assembly of Ile-TMG-Ile at $\mathrm{pH}$ values of 4 through 9 for a period of four weeks. To examine the morphologies of the formed assemblies, we conducted SEM and TEM microscopy. Figure 2 shows the SEM and TEM images of assemblies formed at varying $\mathrm{pH}$. SEM analysis at $\mathrm{pH} 4$ (Figure 2a) indicates the formation of short, thick nanofibers in the diameter range of $500 \mathrm{~nm}$ to $1 \mu \mathrm{m}$, while at $\mathrm{pH} 7$ (Figure 2b) we observed the formation of long, multilayered nanoribbons several micrometers in length, with an average diameter of $500 \mathrm{~nm}$ to $1 \mu \mathrm{m}$. Figure $2 \mathrm{c}$ shows the structures of the assemblies formed under basic conditions ( $\mathrm{pH} 9$ ). Results indicated that under basic conditions, structures of a variety of shapes and sizes (spherical micelles, microtubes and fibers) in the range of $2 \mu \mathrm{m}$ to $5 \mu \mathrm{m}$ in diameter were formed. Corresponding TEM images, also indicated similar morphologies as shown in Figure $2 \mathrm{~d}-\mathrm{f}$ which correspond to assemblies formed at $\mathrm{pH} 4,7$ and 9 respectively. The sizes obtained by the TEM analysis, indicate that the average diameter of the nanofibers formed at $\mathrm{pH} 4$ was found to be $20 \mathrm{~nm}$, while those grown at $\mathrm{pH} 7$ were in the size range of $500 \mathrm{~nm}$ to $1 \mu \mathrm{m}$. The assemblies formed at $\mathrm{pH} 9$ were found to be in the range of $200 \mathrm{~nm}$ to $500 \mathrm{~nm}$. The size differences between TEM and SEM are attributed to the fact that the assemblies are intrinsically multiscale in nature and, vary in sizes. The TEM images display higher resolution and smaller sample sizes are most likely revealed by TEM analysis. Overall, self-assembly of Ile-TMG-Ile was found to be $\mathrm{pH}$ dependent.
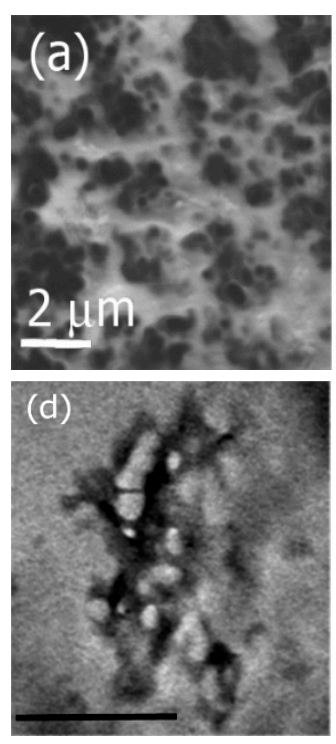
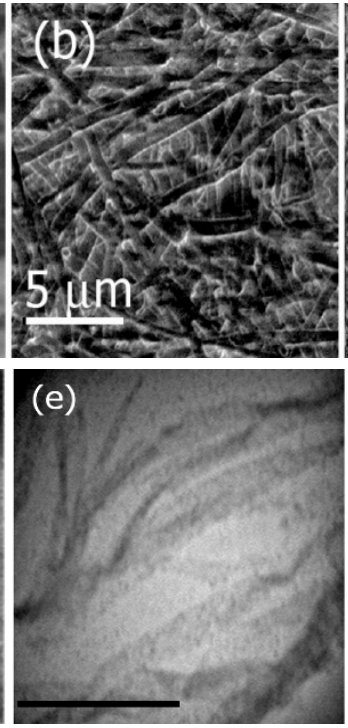
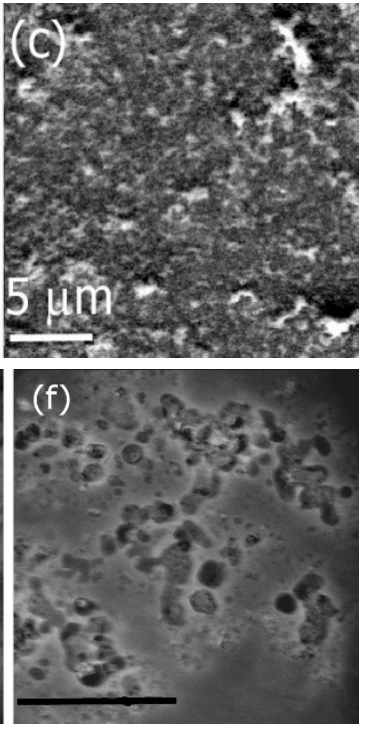

Figure 2. SEM images of Ile-TMG-Ile assemblies formed at (a) $\mathrm{pH} 4$; (b) $\mathrm{pH} 7$ and at (c) $\mathrm{pH}$ 9. TEM images of the assemblies are shown at $(\mathbf{d}) \mathrm{pH} 4$ (scale bar $=500 \mathrm{~nm}) ;(\mathbf{e}) \mathrm{pH} 7($ scale bar $=2 \mu \mathrm{m})$ and (f) $\mathrm{pH} 9$ (scale bar $=1 \mu \mathrm{m} \mathrm{nm}$ ). 
The formation of short, thick nanofibers under acidic conditions is attributed to higher H-bonding interactions under acidic conditions as the carboxylic groups of the side chain isoleucines are likely to be protonated under those conditions. Additionally, assembly formation is promoted due to intermolecular $\mathrm{H}$-bonding interactions between the $-\mathrm{NH}$ and $\mathrm{O}=\mathrm{C}$ groups of the amide groups of the bolaamphiphile. Studies conducted previously with peptide amphiphiles such as bis(N- $\alpha$-amido-glycylglycine)-1,7-heptane dicarboxylate have shown that at a $\mathrm{pH}$ range of 4 to 5 , the formation of nanotubes is promoted due to higher H-bonding interactions and beta-sheet formation [52]. In the case of Ile-TMG-Ile, it is likely that beta-sheet formation is promoted, particularly due to the hydrophobicity of the Ile moieties which have been known to induce nanofiber formation [53]. Under neutral conditions, there appears to be a transition between beta-sheet structures to random coil due to changes in $\mathrm{H}$-bonding interactions as the carboxyl groups are progressively deprotonated, resulting in the formation of uniform nanoribbons. Similar phenomena have been observed in the case of bola-glycolipids where changes in morphologies of supramolecular structures were observed, resulting in nanoribbon formation under neutral conditions. This was primarily attributed to a combination of hydrophobic interactions, chirality as well as well as changes in $\mathrm{pH}$ [54]. Under basic conditions, we observed a mixture of nanostructures as under those conditions the Ile-TMG-Ile bolaamphiphle is completely deprotonated and $\mathrm{H}$-bonding is significantly diminished. Although $\mathrm{C}=\mathrm{O}-\mathrm{NH}$ amide $\mathrm{H}$-bonding still exists under basic conditions, the carboxylate groups are negatively charged under those conditions and may result in repulsion between the negatively charged carboxylate groups. Thus, a variety of structures including micelles and few fibrillar structures are formed due to a combination of hydrophobic interactions, as well as amide-amide H-bonding and uniform assemblies are not formed.

We also monitored the growth of assemblies periodically using dynamic light scattering in all cases and over time. Results obtained after two weeks of growth are shown in Figure 3. As seen in the figure, the assemblies obtained were polydisperse. This is most likely because the assemblies are not uniform. They are mostly fibrillar, or ribbon shaped (in the case of assemblies grown at $\mathrm{pH} 4$ and $\mathrm{pH} 7$ ) or display a variety of morphologies as seen in the case of assemblies grown at $\mathrm{pH}$ 9. It is likely that aggregates of the assemblies at different stages of growth are observed. Overall, due to the formation of ribbon like structures under neutral conditions, we selected those assemblies for preparation of the scaffold.
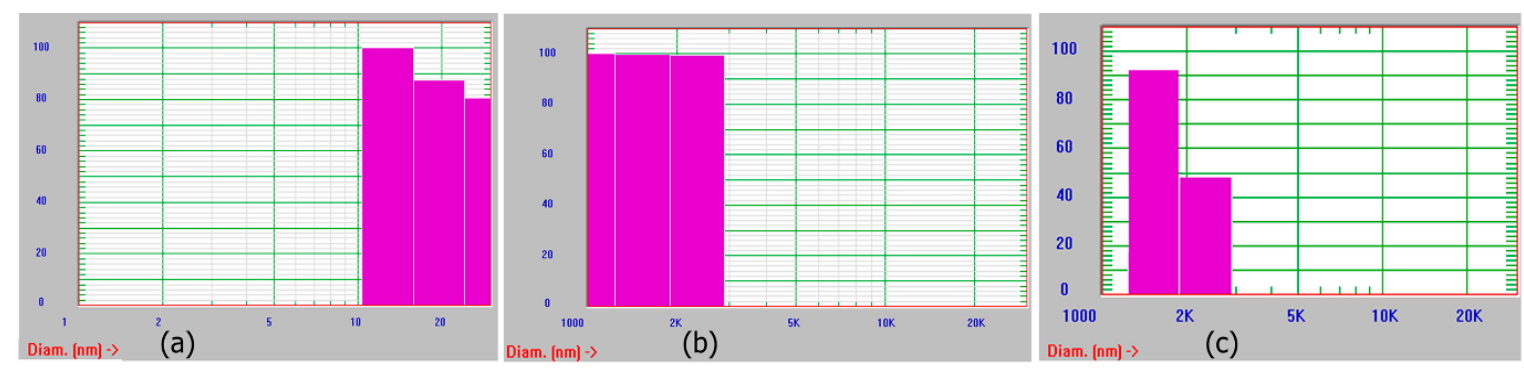

Figure 3. Dynamic light scattering analyses of assemblies formed at (a) $\mathrm{pH} 4$; (b) $\mathrm{pH} 7$ and (c) $\mathrm{pH} 9$.

\subsection{Functionalization of Ile-TMG-Ile and Preparation of Scaffold}

To prepare the scaffolds that can be tailored for potential neural TE applications, we incorporated protein constituents that may aid in neural tissue regeneration due to their specific functional properties. The conjugation of each component was examined by SEM and TEM imaging as shown in Figure 4 . We first conjugated the washed nanoribbons with laminin, a major component of the ECM of neural tissue. Upon incorporation of laminin, changes in morphology were observed (Figure 4a). The SEM image of laminin bound assemblies showed a relatively rough, gelatinous coating on the nanoribbons compared to the smooth surfaces in the absence of laminin as seen in Figure $2 \mathrm{~b}$. The corresponding TEM image (Figure 4e) showed a fibrous mesh like network upon conjugation with laminin. In general, 
laminin consists of both globular and rod-shaped domains and forms alpha-helical coiled coil structures [55]. Upon conjugation with the nanoribbons, laminin binds to nanoribbons, forming a gelatinous network intertwined with the nanoribbons. In general, laminin has been known to polymerize and form laminin networks, in cells due to interactions between the $\alpha$-short arms of the amino terminal domain and $\beta$ and $\gamma$-short arms of laminin [56]. It is likely that it wraps around Ile-TMG-Ile nanoribbon assemblies upon conjugation resulting in the mesh like networks.

Upon conjugation with artemin, further morphology changes were observed. In the SEM image (Figure 4b), we observed the incorporation of globular, rosette like structures throughout the gelatinous matrix. Similar structures were observed in the in the corresponding TEM image (Figure 4f). Previous studies have revealed that artemin monomers tend to self-assemble into rosette-like oligomers [57] and it is also known to be an exceptionally stable neurotrophic factor that can induce changes in the folding process of proteins as it functions as a molecular chaperone [58]. Thus, the morphology changes observed on the surfaces of the laminin bound nanoribbons further confirm the successful conjugation of artemin. We then conjugated the composite nanoribbons with Type IV collagen (Figure 4c,g). SEM and TEM images confirmed morphological changes after incorporation of Type IV collagen as the formation of large fibrillar mesh like structures were observed, integrated with rosette structures of artemin. In several studies, it has been shown that collagens tend to form long fibrillar structures, due to the formation of triple-helices and impart structural integrity to scaffolds [59]. Thus, our results confirm the formation of the biocomposite nanoribbons integrated with laminin, artemin and Type IV collagen. To impart electrical properties, essential for developing scaffolds for neural TE, we then incubated the conductive polymer polyaniline (PANI) with the biocomposite scaffolds. Previous studies have shown that PANI in the presence of dopants can self-assemble into nanostructures [60]. The presence of the amine groups of PANI, allow for electrostatic and H-bonding interactions between the carbonyl groups of the protein bound nanoribbons and PANI. Additionally, stacking interactions with the aromatic ring systems of PANI are also promoted between the proline and hydroxyproline moieties of Type IV Collagen. Distinct changes in morphology were observed upon incorporation of PANI into the biocomposite (Figure $4 \mathrm{~d}$,h) showing the formation of aggregates of PANI on the scaffold indicating its successful assimilation.
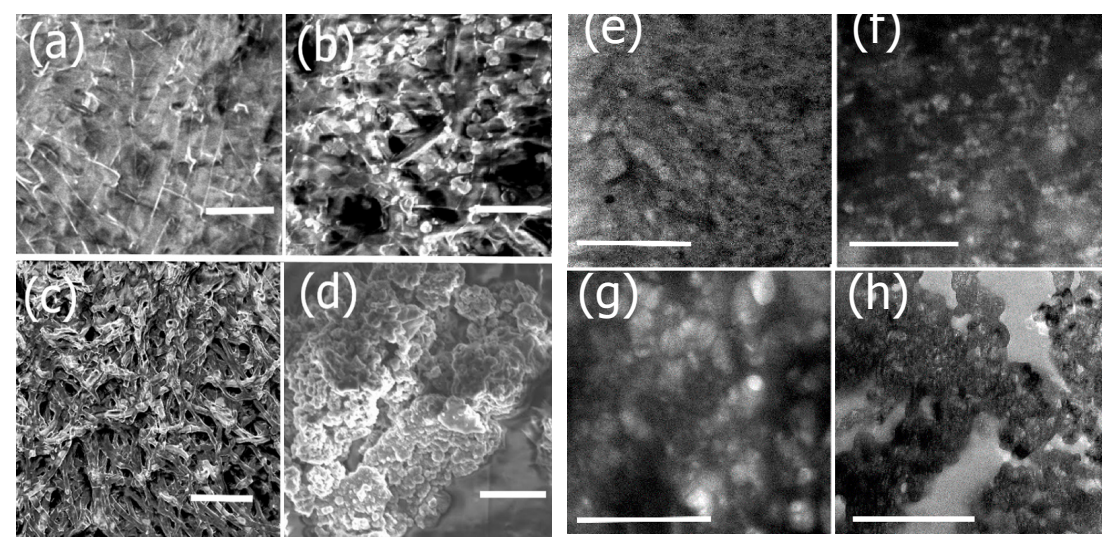

Figure 4. SEM and TEM images showing morphology changes after functionalization with each component. (a) SEM image of nanoribbons functionalized with laminin (scale bar $=2 \mu \mathrm{m}$ ); (b) SEM image showing subsequent conjugation with Artemin (scale bar $=2 \mu \mathrm{m}$ ); (c) SEM image after incorporation of Type IV collagen to laminin-artemin-bound nanoribbons (scale bar $=5 \mu \mathrm{m}$ ); (d) SEM image after incorporation of PANI to the functionalized biocomposite (scale bar $=5 \mu \mathrm{m}$ ). (e) TEM image of nanoribbons functionalized with laminin (scale bar = $2 \mu \mathrm{m}$ ); (f) TEM image showing subsequent conjugation with Artemin (scale bar $=2 \mu \mathrm{m})$; $(\mathrm{g})$ TEM image after incorporation of Type IV collagen to laminin-artemin-bound nanoribbons (scale bar $=3 \mu \mathrm{m}$ ); (h) TEM image after incorporation of PANI to the functionalized biocomposite (scale bar $=3 \mu \mathrm{m}$ ). 


\subsection{FTIR Spectroscopy}

To further confirm the formation of the scaffold, we conducted FTIR spectroscopy (Figure 5). As shown in Figure $5 a$, the self-assembled template nanoribbons showed characteristic peaks in the amide I region at $1658 \mathrm{~cm}^{-1}$ and at $1650 \mathrm{~cm}^{-1}$ with a shoulder at $1634 \mathrm{~cm}^{-1}$ along with peaks at $1450 \mathrm{~cm}^{-1}$ and $1413 \mathrm{~cm}^{-1}$ in the amide II region. These peaks are indicative of formation of a mix of random coil, alpha helical and beta-sheet structures [61] that resulted in the formation of nanoribbons. Previous studies using protein analogs with $C$ terminus isoleucine are consistent with these findings of mostly alpha helical and random coil structures [62]. Additionally, a strong peak was observed at $1286 \mathrm{~cm}^{-1}$ and at $1075 \mathrm{~cm}^{-1}$, attributed to $\mathrm{C}-\mathrm{O}$ and $\mathrm{C}-\mathrm{H}$ stretching respectively. Upon conjugation with laminin (Figure 5b), the amide I peaks were observed at $1656 \mathrm{~cm}^{-1}$ and at $1628 \mathrm{~cm}^{-1}$ indicating increased beta-sheet formation along with the presence of alpha helices. The amide II peaks were observed at $1550 \mathrm{~cm}^{-1}$ and at $1519 \mathrm{~cm}^{-1}$ while the $\mathrm{C}-\mathrm{O}$ and $\mathrm{C}-\mathrm{H}$ stretching peaks were seen at $1295 \mathrm{~cm}^{-1}$ and at $1059 \mathrm{~cm}^{-1}$ respectively [63]. It has been reported that laminins generally tend to polymerize into sheet like structures [64], which is consistent with our results. Furthermore, similar shifts were also seen after incorporation of laminin onto a poly(l-lactide-co- glycolide) scaffold, indicating successful conjugation of laminin with the nanoribbons [65]. After conjugation with artemin (Figure 5c), further shifts were observed. The amide I band was shifted to $1632 \mathrm{~cm}^{-1}$ with a shoulder at $1662 \mathrm{~cm}^{-1}$ while the amide II peaks shifted to $1535 \mathrm{~cm}^{-1}$ and $1514 \mathrm{~cm}^{-1}$. The C-O and C-H stretching peaks were observed at $1299 \mathrm{~cm}^{-1}$ and at $1064 \mathrm{~cm}^{-1}$ with a shoulder at $1054 \mathrm{~cm}^{-1}$ respectively. These peaks are indicative of increase in beta-sheets along with the appearance of beta-turn structure.

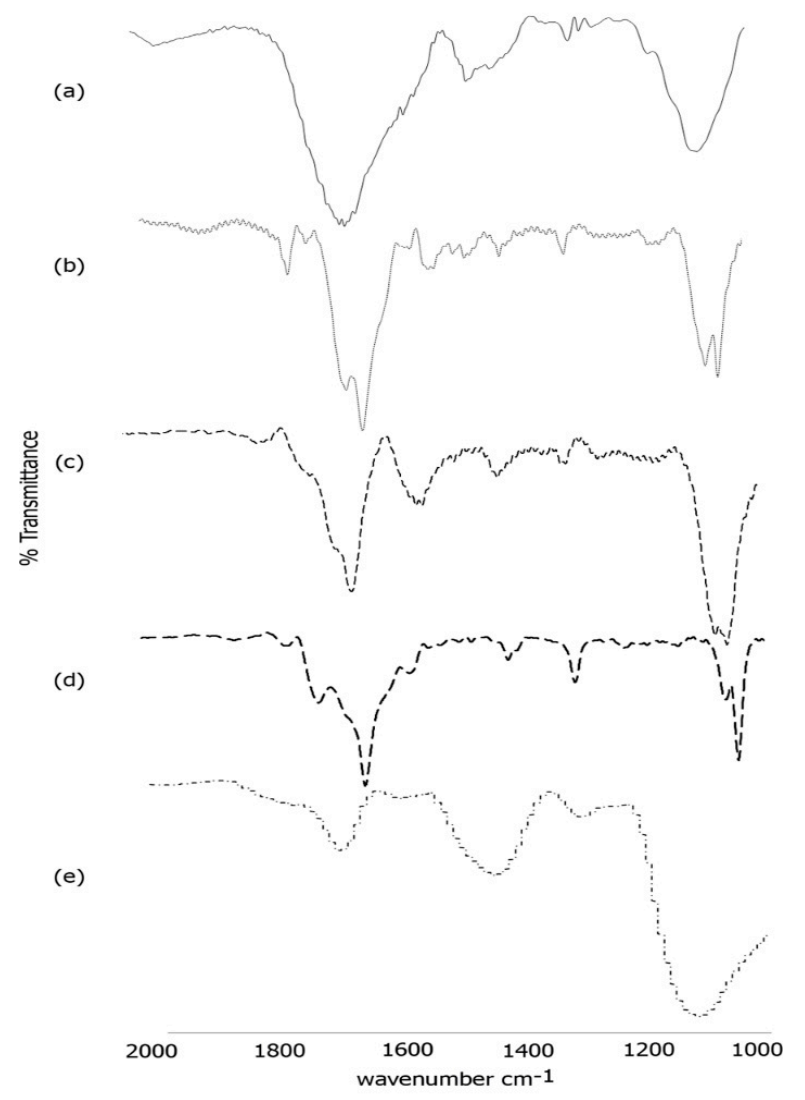

Figure 5. FTIR spectra of (a) self-assembled Ile-TMG-Ile nanoribbons; (b) Nanoribbons bound to laminin; (c) Artemin conjugated with laminin bound nanoribbons; (d) Type IV collagen conjugated with artemin-laminin bound nanoribbons; (e) PANI bound to Type IV collagen-artemin-laminin bound nanoribbons. 
Upon incorporation of Type IV collagen (Figure 5d), the FTIR spectra showed peaks in the amide I region at $1629 \mathrm{~cm}^{-1}$ with a shoulder at $1652 \mathrm{~cm}^{-1}$ and a peak at $1699 \mathrm{~cm}^{-1}$. The amide II peak was found to be at $1558 \mathrm{~cm}^{-1}$ while the $\mathrm{C}-\mathrm{O}$ and C-H stretching peaks were observed at $1293 \mathrm{~cm}^{-1}$ and at $1035 \mathrm{~cm}^{-1}$ respectively. These changes confirm the incorporation of Type IV collagen. Furthermore, the secondary structure reveals the presence of alpha-helical content along with beta-strands and $\beta$ and $\gamma$-turns [66] due to blending of Type IV collagen with artemin-laminin bound nanoribbons. Distinct changes were observed upon incorporation of PANI. As seen in Figure 4e, peaks were found at $1680 \mathrm{~cm}^{-1}, 1560 \mathrm{~cm}^{-1}$ and at $1430 \mathrm{~cm}^{-1}, 1280 \mathrm{~cm}^{-1}$ and at $1112 \mathrm{~cm}^{-1}$. The peaks at $1630 \mathrm{~cm}^{-1}$ at $1450 \mathrm{~cm}^{-1}$ are indicative of vibrations from quinoid rings and benzenoid ring systems as seen in PANI bound polystyrene nanocomposites [67]. These results further confirm the formation of the composite scaffold.

\subsection{Fluorescence Microscopy}

In order to confirm that the proteins retained biological activity after conjugation with the assemblies, we examined the binding affinity of the laminin bound assemblies as well as the Type IV collagen bound biocomposites with corresponding antibodies. We used FITC labeled laminin -2 antibody (B-4) for laminin bound assemblies and rhodamine labeled anti-collagen (Type IV) antibody for Type IV collagen bound biocomposites respectively and examined the interactions using fluorescence microscopy. In previous work, it has been shown that conjugation of different biological moieties including specific peptide sequences such as RGD, TAT peptides, or proteins such as transferrin, antibodies with nanomaterials not only increases the stability of the proteins but also enhances the applications of the nanomaterials themselves [68]. Furthermore, such conjugations allow for interactions with cell receptors or biological membranes, thereby promoting the use of such materials for a variety of biomedical applications. As shown in Figure 6, FITC conjugated anti-laminin bound antibodies efficiently bound to the laminin bound assemblies, (Figure 6a) and rhodamine conjugated anti-collagen IV antibodies bound to the biocomposite (Figure $6 \mathrm{~b}$ ). These results confirmed that laminin and Collagen IV retained their biological activity upon binding with the assemblies.
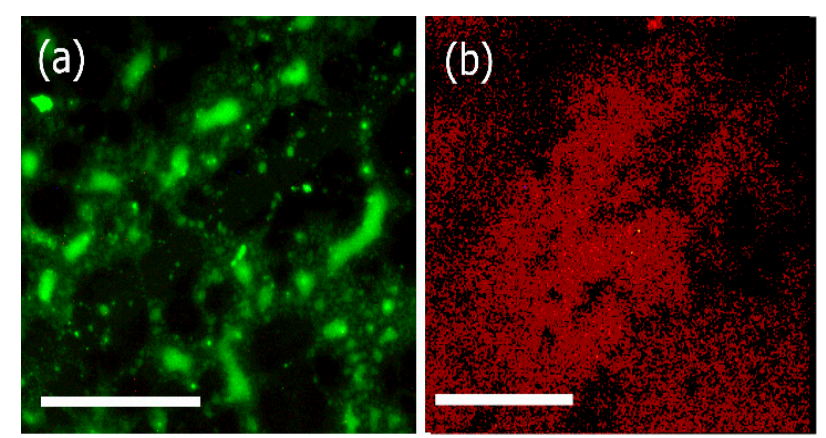

Figure 6. Fluorescence microscopy images of (a) FITC labeled laminin $\alpha-2$ antibody bound to laminin bound assemblies; (b) Rhodamine labeled collagen IV antibody bound to biocomposite assemblies (collagen IV-artemin-laminin bound Ile-TMG-Ile). Scale bars $=20 \mu \mathrm{m}$.

\subsection{Differential Scanning Calorimetry}

In order to explore the thermal properties, we examined phase changes of the assemblies before and after conjugation with each component utilized in the formation of the scaffold (Figure 7). Short endothermic peaks were observed in the case of the Ile-TMG-Ile assemblies (Figure 7a) at $14.9^{\circ} \mathrm{C}$ and at $36.7{ }^{\circ} \mathrm{C}$ followed by another endothermic peak at $99.6^{\circ} \mathrm{C}$, due to loss of loosely bound water. After functionalization with laminin, (Figure $7 \mathrm{~b}$ ) a large, broad endothermic peak was observed in the temperature range of $50{ }^{\circ} \mathrm{C}$ to $100{ }^{\circ} \mathrm{C}$, followed by shallow endothermic peaks at $172.4{ }^{\circ} \mathrm{C}$ and at $232.1^{\circ} \mathrm{C}$. The significantly broad endothermic peak at the lower temperature is indicative loss of 
free water, due to the presence of hydrophilic amino acids in the protein. This is primarily due to the fact that hydrophilic groups can cause significant hydration and upon heating, changes in H-bonding interactions and consequently conformation changes in the laminin bound nanoribbons occur. This is a common occurrence in self-assembled peptides and proteins due to the rearrangement of components because of changes in inter and intra-molecular interactions [69]. The short peak at $171.4^{\circ} \mathrm{C}$ is likely due to thermal melting, followed by crystallization at a higher temperature $\left(232.1^{\circ} \mathrm{C}\right)$. After further functionalization with artemin (Figure 7c) a similar broad endothermic peak was observed in the temperature range of $50{ }^{\circ} \mathrm{C}$ to $100{ }^{\circ} \mathrm{C}$, (though the intensity was lower). Slight shifts were observed in the higher temperature range, with the thermal melting appearing at $172.6^{\circ} \mathrm{C}$ and the subsequent short crystallization peak was observed at $242.1^{\circ} \mathrm{C}$. Upon binding with Type IV collagen, (Figure $7 \mathrm{~d}$ ) the composite once again showed a broad endothermic peak, between $50^{\circ} \mathrm{C}$ to $100{ }^{\circ} \mathrm{C}$, though the intensity of the peak was lesser than the previous layer, due to higher cross-linking in the presence of collagen and notably, peaks at higher temperature were diminished.

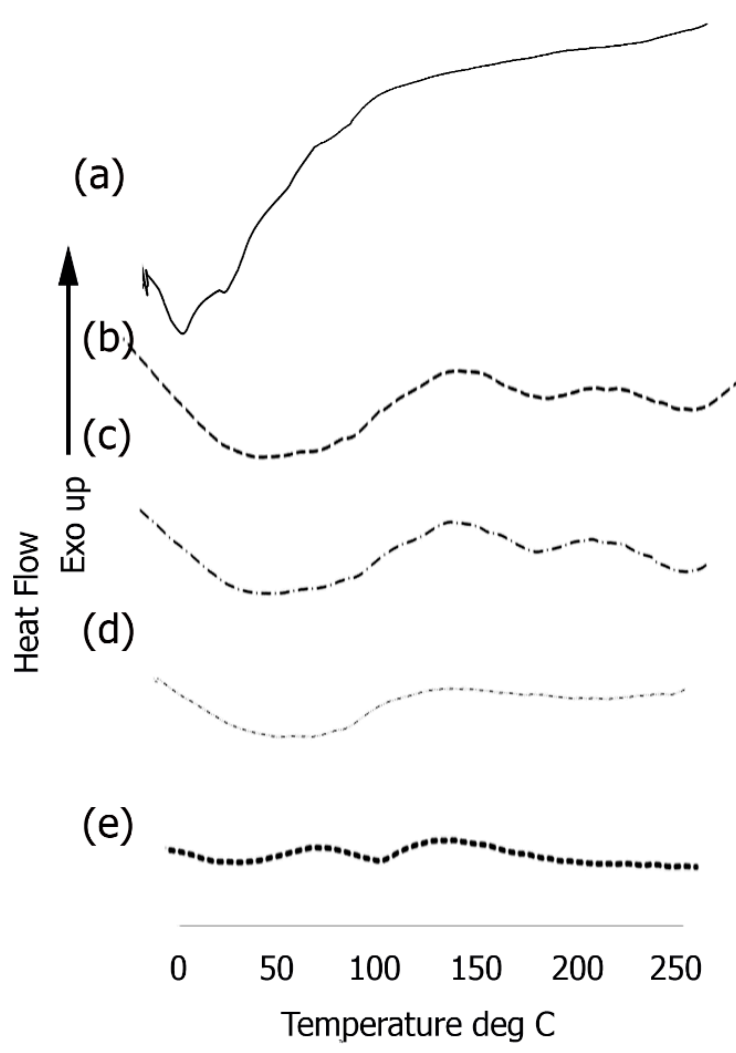

Figure 7. DSC thermograms of (a) self-assembled Ile-TMG-Ile nanoribbons; (b) Nanoribbons bound to laminin; (c) Artemin conjugated with laminin bound nanoribbons; (d) Type IV collagen conjugated with artemin-laminin bound nanoribbons; (e) PANI bound to Type IV collagen-artemin-laminin bound nanoribbons.

However, a significant change was observed upon incorporation of PANI (Figure 7e), where in the intensity of the broad endothermic peaks seen in the protein bound scaffold was significantly reduced. Relatively short endothermic peaks are observed at $52{ }^{\circ} \mathrm{C}$ and at $102{ }^{\circ} \mathrm{C}$ due loss of loosely bound water and no other significant peaks are observed. PANI is significantly hydrophobic compared to the proteinaceous components, resulting in shallow peaks due to loss of free unbound water. These results further confirm the integration of PANI. 


\subsection{Mechanical and Surface Properties}

It is paramount that the designed scaffolds should be able to bear force loads in order to adequately support seeded cells and potentially boost the formation of new tissue. We utilized peak force microscopy to determine the mechanical properties of the scaffold. In general, nanoindentation was carried out using AFM to examine the changes in attractive and repulsive forces and the depth of indentation as the tip of the cantilever contacts the sample and is deformed. At least three to five points were selected for each sample to obtain force vs. separation curves and the data obtained was fit into Hertzian model to obtain the Young's modulus. The results obtained for average Young's Modulus values after incorporation of each of the components of the scaffold are shown in Table 1.

Table 1. Youngs Modulus values of constructs after consecutive incorporation of each layer.

\begin{tabular}{cc}
\hline Construct & Young's Modulus (GPa) \\
\hline Self-Assembled nanoribbons & 0.757 \\
Nanoribbons bound to Laminin & 1.805 \\
Nanoribbons bound to Laminin-Artemin-Collagen & 2.985 \\
Nanoribbons bound to & 5.522 \\
Laminin-Artemin-Collagen-PANI & \\
\hline
\end{tabular}

These results indicate that as each protein layer was conjugated with the nanoribbons, the Young's Modulus (YM) was found to increase, demonstrating that each protein component consecutively increased the stiffness and mechanical strength of the scaffold. The YM values obtained were for dried scaffolds alone and are most likely higher than those one would expect for wet scaffolds, under in vivo or in vitro conditions. Previous nanoindentation studies have shown that native single collagen fibrils have an YM value in the range of 1 to $2 \mathrm{GPa}$ [70]. It has also been reported that protein structures and self-assembled collagen based constructs designed to have properties to mimic the extracellular matrix display Young's Moduli averaging 1.2 GPa [71]. We also determined the Young's Modulus of control Type IV collagen by nanoindentation and the YM was found to be $532.2 \pm 3 \mathrm{MPa}$, while control PANI films were found to have a YM of $1.52 \pm 5 \mathrm{GPa}$. Thus, our results indicate that for the protein functionalized nanoribbon biocomposite, the overall mechanical strength of the scaffold increases due to the multi-component nature of the scaffold. Furthermore, it was found that the highest YM value was obtained after incorporation of PANI. A comparison of AFM images of scaffolds before and after incorporation of PANI and the corresponding force curves are shown in Figure 8.

AFM topography images indicate that the surface of the bicomposite before binding to PANI (Figure 8a) shows a more fibrillar structure, due to top layer of the scaffold being Type IV collagen, while after binding to PANI, more globular structures were observed to be deposited on the scaffold (Figure 8b). These results indicate changes in surface roughness and morphology of the scaffold after incorporation of PANI. Additionally, the force-curves also showed significant changes upon binding with PANI (Figure $8 \mathrm{c}, \mathrm{d}$ ). These results are consistent with previous nanoindentation studies, where it has been demonstrated that when PANI was deposited on vertical arrays of carbon nanotubes (CNTs), the Young's Modulus value dramatically increased due to strong electrostatic and $\pi-\pi$ stacking interactions with CNTs [72]. It is expected that similar interactions occur between the biocomposite and PANI that leads to a higher YM. In general, the Young's Modulus values of pyrrolidinone and polyaniline films have been reported to be in the range of $200 \mathrm{MPa}-5 \mathrm{GPa}$ [73]. Thus, our results after incorporation of PANI with the biocomposite scaffold are within the values reported previously in the literature.

We also probed the changes in the surface roughness of the scaffold before and after incorporation of PANI. In general, it is known that surface roughness plays a key role in cell adhesion of scaffolds [74] For instance, it has been shown that silk fibroin bound PLA fibers with higher surface roughness promoted increased growth and adhesion of osteoblast cells [75]. For the biocomposite scaffold before incorporation of PANI, the average surface roughness ( $\mathrm{Ra}$ ) was found to be $154 \mathrm{~nm}$, while the 
maximum roughness (Rmax) was determined to be $209 \mathrm{~nm}$. We found that incorporation of PANI resulted in a significant increase in the surface roughness. The Ra was found to be $377 \mathrm{~nm}$ and the Rmax was found to be $2065 \mathrm{~nm}$, further confirming the formation of the composite.
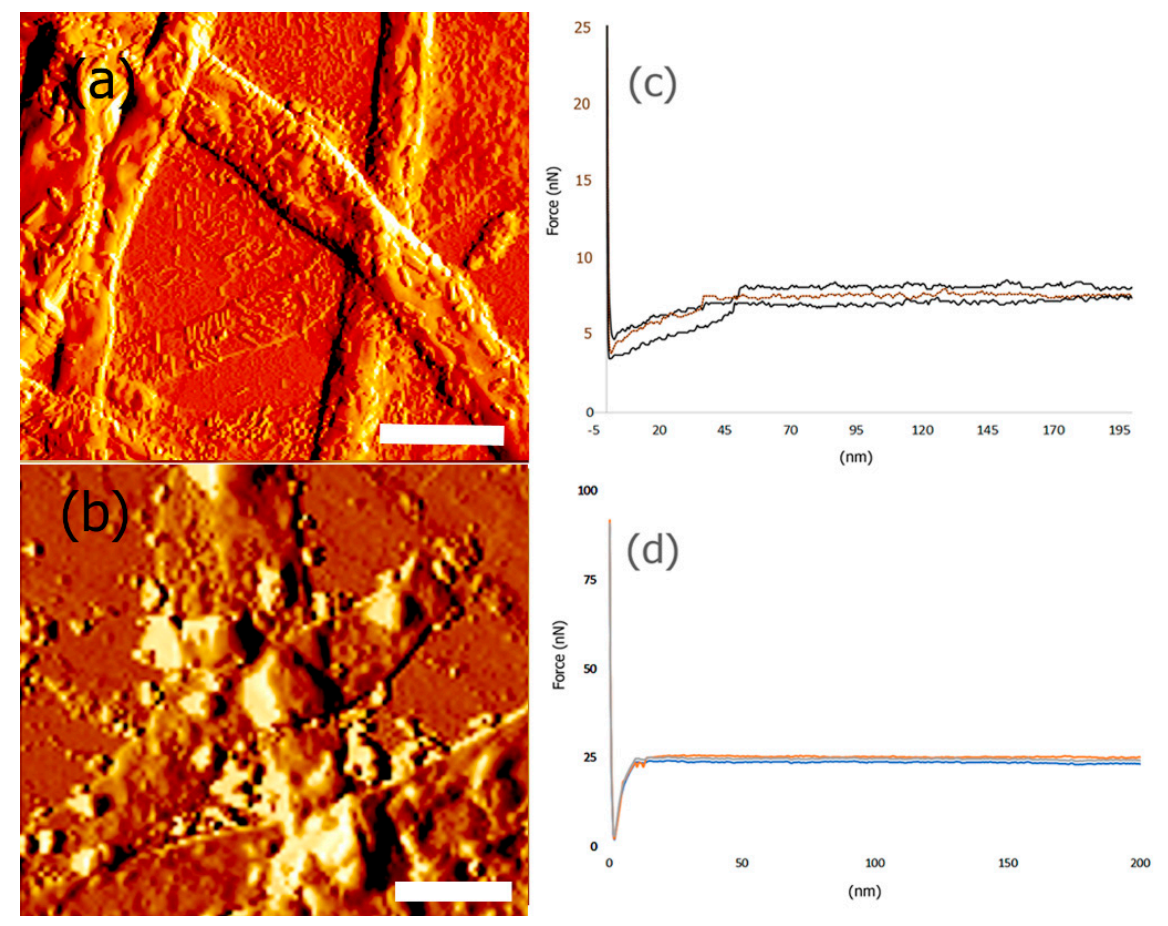

Figure 8. AFM amplitude image of (a) biocomposite nanoribbons bound to laminin, artemin and collagen. Scale Bar $=10 \mu \mathrm{m}$; (b) nanoribbons bound to laminin, artemin and collagen and PANI. Scale Bar $=5 \mu \mathrm{m}$. (c) Force curves obtained for biocomposite nanoribbons bound to laminin, artemin and collagen; (d) Force curves obtained for nanoribbons bound to laminin, artemin and collagen and PANI.

\subsection{In Vitro Biodegradability Studies}

When developing a scaffold for tissue engineering, the biodegradability of a scaffold plays a vital role. It has been reported that biodegradability promotes growth and proliferation of cells, as well as production of native ECM [76]. In comparison to non-biodegradable scaffolds, biodegradable composites are able to aid in the growth of new tissues at a highly expedited rate due to the increased proliferation and lack of hindrance for cell growth [77]. We examined the biodegradability of the formed scaffold in simulated body fluid buffer in order to mimic in vivo conditions. Figure 9 shows the results obtained over a period of three weeks in simulated body fluid. The scaffold shows a mass loss of $48.7 \%$ after 22 days. Overall, the scaffold showed degradation at a moderate rate, which is preferential to highly vascular nervous tissue [78]. This result is consistent with other polymer and basement membrane mimicking scaffolds for tissue engineering; such as, poly(3-hydroxybutyric acid) with chitin and chitosan which demonstrated biodegradability from $45-70 \%$ and collagen, hyaluronic acid and gelatin scaffolds which demonstrated $45 \%$ biodegradability [79]. 


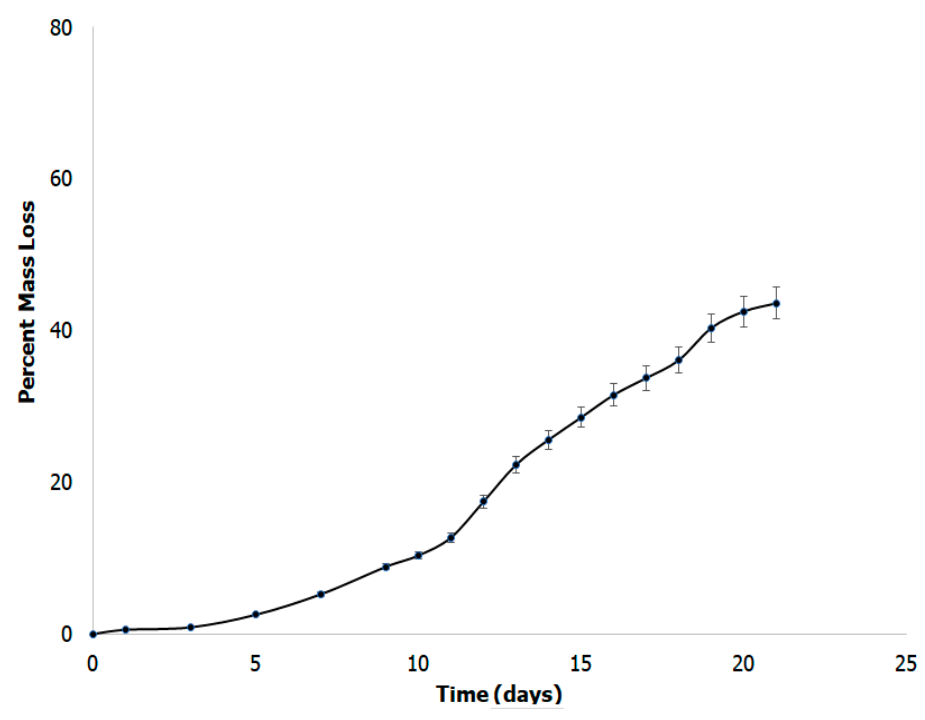

Figure 9. Biodegradation studies of the scaffolds showing mass loss over a period of 20 days.

\subsection{Cell Studies}

To examine if the formed scaffolds would be suitable for applications in neural TE, we conducted cell viability studies with rat neural cortical cells. We examined the effects of scaffolds before and after incorporation of PANI as shown in Figure 10. The data shown are representative of results obtained in the presence of $10 \mu \mathrm{M}$ scaffolds in comparison with control untreated cells. Our results indicate that the cells continued to proliferate over a period of $72 \mathrm{~h}$ in the presence of scaffolds. Although cell proliferation continued over time, the rate of cell growth for the PANI bound construct was lower compared to the controls due to the known cytotoxicity of PANI [80]. This is most likely that proliferation continued due to the synergistic effects of the protein components of the scaffolds, which play a role in enhancing biocompatibility of the PANI bound scaffold. Previous studies have shown that laminin bound nanofibers significantly increased the attachment and neurite extension of cells in vitro [81] while artemin promotes axonal growth in damaged neural tissue, as well as regeneration of sensory neurons [82]. Other research has shown that after damage, artemin increases survivability of injured neurons [83]. The incorporation of Type IV collagen increases the influx of nutrients to growing and damaged neural tissue, increasing new growth and proliferation. We also studied the growth and proliferation in the presence of $6 \mu \mathrm{M}$ and $13 \mu \mathrm{M}$ scaffolds which showed similar trends of cell viability (data not shown). In general, no significant differences were observed in the proliferation at varying concentrations of the scaffold. These results indicated growth and proliferation of cortical cells continued and were comparative to the control throughout various time periods and concentrations of the construct.

To further investigate the cell proliferation of neural cortical cells and morphologies in the presence and absence of PANI bound scaffolds, we conducted phase contrast optical microscopy studies. The results obtained are shown in Figure 11. As seen in the figure, there was a major difference in the morphologies of the cells grown in the presence of PANI bound scaffolds over a period of seven days in comparison to those after $48 \mathrm{~h}$. As shown in Figure 11a,b, in the absence of scaffold, cells continued to proliferate over time. However, we did not observe cluster formation or axonal outgrowths. Upon incubation with PANI bound scaffolds. After $48 \mathrm{~h}$ (Figure 11c), the cells appeared to relatively more elongated compared to controls However after seven days, we observed cluster formation and axonal outgrowth (Figure 11d). These results indicated that the cells efficiently continued to proliferate in the presence of the PANI bound scaffolds and enhanced neural cell growth as well as cell-cell adhesion, further confirming that the scaffolds were conducive to forming cell-scaffold matrices and provide an environment for the growth and support of neural cortical cells. 


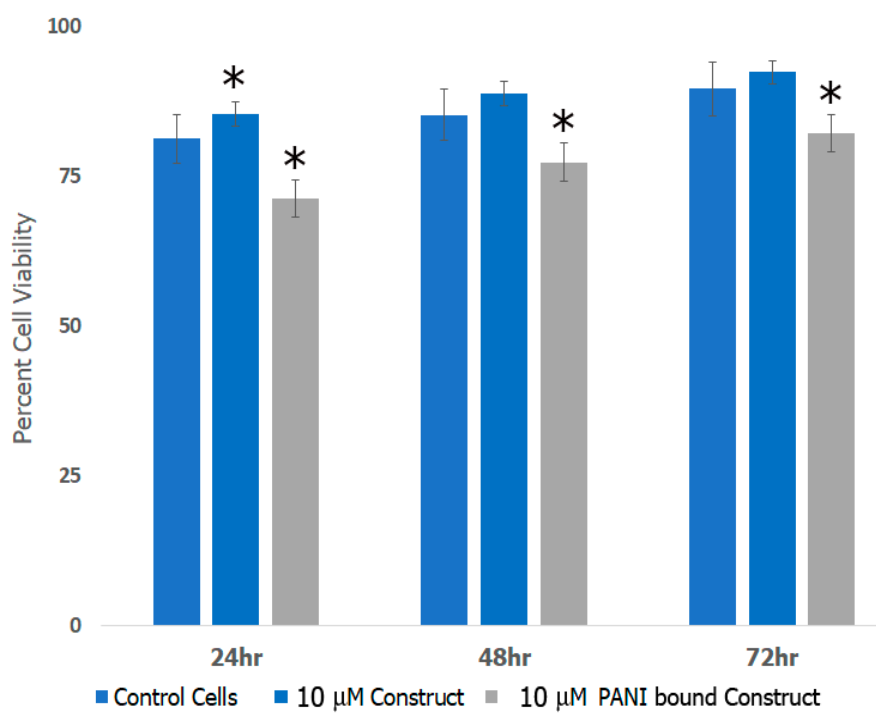

Figure 10. Cortical cell viability in the presence of scaffold constructs before and after incorporation of PANI. $\left({ }^{*}=p<0.05\right.$ was determined to be statistically significant).

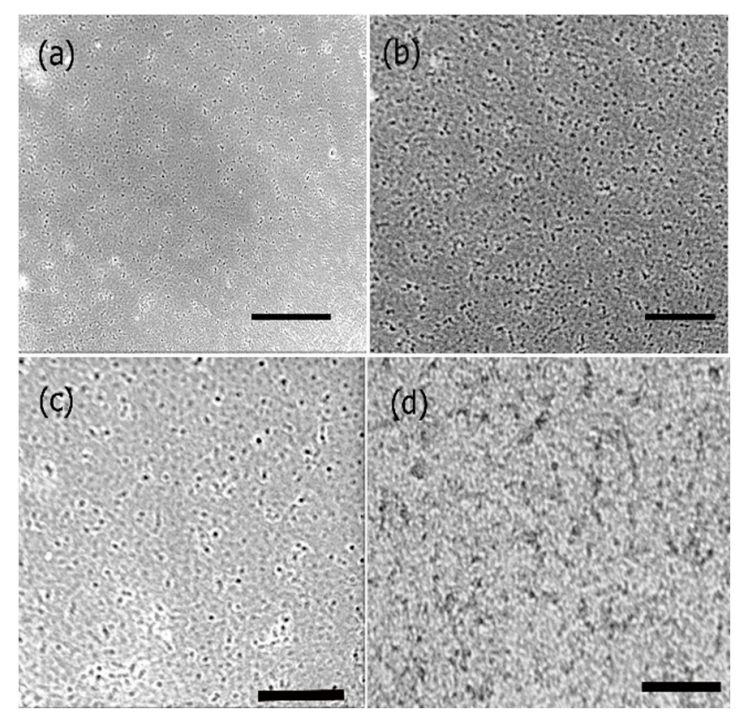

Figure 11. Phase contrast microscopy images showing the growth of neural cortical cells (a) control cells after $24 \mathrm{~h}$; (b) control cells after $72 \mathrm{~h}$; (c) cells with PANI bound scaffolds after $48 \mathrm{~h}$ and (d) cells with PANI bound scaffolds after 7 days. Scale bars: (a) $50 \mu \mathrm{m}$; (b) $50 \mu \mathrm{m}$; (c) $30 \mu \mathrm{m}$; (d) $50 \mu \mathrm{m}$.

\subsection{Cyclic Voltammetry}

To examine the electrochemical properties of the PANI bound scaffold, cyclic voltammetry was conducted. Prior to performing the experiment, the control PANI or the scaffold bound PANI were dried onto the platinum electrodes in vacuum overnight. After connecting the electrodes to the potentiostat, nitrogen was bubbled into the $\mathrm{HCl}$ cell solution to remove oxygen from the solution. Potential between $-0.2 \mathrm{~V}$ to $0.9 \mathrm{~V}$ was applied at $10 \mathrm{mV} / \mathrm{s}$ to obtain $\mathrm{I}-\mathrm{V}$ curves. At a voltage of $0.1 \mathrm{mV}$, an anodic oxidation peak was observed of approximately $2.6 \times 10^{-7}$ Amps current, with a corresponding cathodic reduction peak at $0.27 \mathrm{mV}$ of approximately $-2.85 \times 10^{-7}$ Amps current in the case of the control PANI. Cyclic voltammetry was then conducted with scaffold bound PANI. Our results indicated that oxidation peaks were observed at $0.213 \mathrm{mV}$ at $1.13 \times 10^{-5}$ amps current and at $0.56 \mathrm{mV}$ at $1.12 \times 10^{-5}$ Amps which correspond to the lecuoemeraldine-emeraldine and 
emeraldine-pernigraniline oxidation processes [84]. The reduction peaks were observed at cathodic currents of $-1.39 \times 10^{-5}$ Amps and at $-1.54 \times 10^{-5}$ Amps at $0.67 \mathrm{mV}$ and at $0.32 \mathrm{mV}$ respectively. These results are shown in Figure 12. Similar cyclic voltagrams have been observed for electrospun polycaprolactone and polyaniline fibers used in skeletal tissue engineering [85].

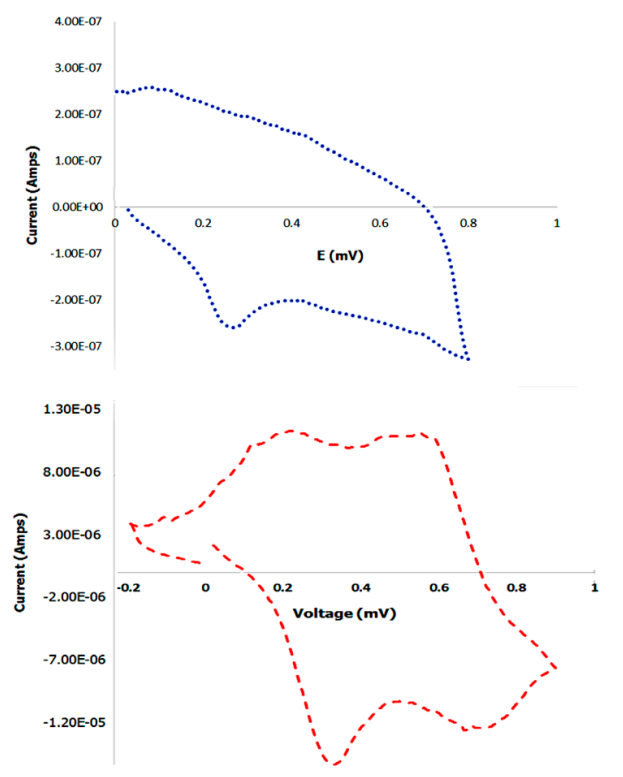

Figure 12. Comparison of cyclic voltagrams of control PANI (top) and PANI bound scaffold (bottom).

Cyclic voltammetry of polyaniline-carbon nanotubes also yielded similar voltammograms [86]. We also compared the cyclic voltagrams with scaffolds formed before incorporation of PANI which did not show any peaks (data not shown). To further examine the electrical properties of the scaffolds, we measured the resistance of the scaffolds to determine the conductivity. Our results showed that the PANI bound scaffolds displayed a conductance of $1.5 \times 10^{-3} \mathrm{~S} / \mathrm{cm}$; while the scaffolds in the absence of PANI displayed zero conductivity. Control PANI displayed a conductivity of $2.0 \times 10^{-3} \mathrm{~S} / \mathrm{cm}$, which was higher than the PANI bound scaffolds. Overall, these results are indicative that upon binding to PANI the scaffolds display electrical properties, compared to absence of PANI, which is essential for scaffolds for neural tissue regeneration.

\section{Conclusions}

In this work, 3,3 tetramethyleneglutaric acid and isoleucine were coupled and allowed to self-assemble into a nanoribbon matrix. The nanoribbons were then functionalized with laminin, a primary component in the neural cell basement membrane, along with artemin a glial cell line derived neurotropic factor and Type IV collagen another key component of the ECM of neural tissues. To impart electrical properties, we then incorporated polyaniline a conductive polymer into the scaffold matrix. Peak force microscopy studies revealed that the scaffolds had high mechanical strength and the Young's Modulus increased with conjugation with each protein layer. The scaffolds also displayed biodegradability. Furthermore, the scaffolds were found to promote cell proliferation and encouraged neurite outgrowths. Although cell proliferation was relatively lower for the PANI bound scaffolds, compared to scaffolds without PANI, our results indicated that the biological components of the scaffold overall aided in cell growth. Additionally, cyclic voltammetry conducted showed that PANI bound scaffolds displayed electrochemical properties. Thus, we have created supramolecular composite scaffolds that may be have applications in neural tissue engineering. 
Acknowledgments: Andrew M. Smith and Harrison T. Pajovich would like to thank Fordham University Research Grants for financial support of this work. Ipsita A. Banerjee thanks NSF MRI Grant No. 1626378 for support of this work. The authors would also like to thank McMahon for his suggestions and help with the conductivity studies and Fath at the Queens College core facility for Imaging, Cellular and Molecular Biology for the use of the transmission electron microscope

Author Contributions: Andrew M. Smith synthesized the scaffolds, performed experiments and worked on data acquisition for the various studies conducted. Andrew M. Smith was also involved in writing the initial drafts. Harrison T. Pajovich performed some of the analytical experiments. Ipsita A. Banerjee conceived and designed the experiments, analyzed the data and wrote the paper.

Conflicts of Interest: The authors declare no conflict of interest. The founding sponsors had no role in the design of the study; in the collection, analyses, or interpretation of data; in the writing of the manuscript and in the decision to publish the results.

\section{References}

1. Saaty, T. Neurons the decision makers, Part I: The firing function of a single neuron. Neural Netw. 2017, 86, 102-114. [CrossRef] [PubMed]

2. Hammond, C.; Cayre, M.; Panatier, A.; Avignone, E. Neuron-glial cell cooperation. In Cellular and Molecular Neurophysiology, 4th ed.; Academic Press: Cambridge, MA, USA, 2015; pp. 25-37. ISBN 9780123970329.

3. Katsu-Jiménez, Y.; Alves, R.M.P.; Giménez-Cassina, A. Food for thought: Impact of metabolism on neuronal excitability. Exp. Cell Res. 2017, 36, 41-46. [CrossRef] [PubMed]

4. Gupta, M.K.; Jayaram, S.; Madugundu, A.K.; Chavan, S.; Advani, J.; Pandey, A.; Thongboonkerd, V.; Sirdeshmukh, R. Chromosome-centric human proteome project: Deciphering proteins associated with glioma and neurodegenerative disorders on chromosome 12. J. Proteome Res. 2014, 13, 3178-3190. [CrossRef] [PubMed]

5. Yu, X.; Bellamkonda, R.V. Tissue-Engineered scaffolds are Effective alternatives to autografts for bridging peripheral nerve gaps. Tissue Eng. 2003, 9, 421-430. [CrossRef] [PubMed]

6. Otto, R.; Penzis, R.; Gaube, F.; Adolph, O.; Föhr, K.J.; Warncke, P.; Robaa, D.; Appenroth, D.; Fleck, C.; Enzensperger, C.; et al. Evaluation of homobivalent carbolines as designed multiple ligands for the treatment of neurodegenerative disorders. J. Med. Chem. 2015, 58, 6710-6715. [CrossRef] [PubMed]

7. Carriel, V.; Alaminos, M.; Garzón, I.; Campos, A.; Cornelissen, M. Tissue engineering of the peripheral nervous system. Expert Rev. Neurother. 2014, 14, 301-318. [CrossRef] [PubMed]

8. Williams, D. Benefit and risk in tissue engineering. Mater. Today 2004, 7, 24-29. [CrossRef]

9. Evans, N.D.; Gentleman, E.; Polak, J.M. Scaffolds for stem cells. Mater. Today 2006, 9, 26-33. [CrossRef]

10. Gu, X.; Ding, F.; Williams, D.F. Neural tissue engineering options for peripheral nerve regeneration. Biomaterials 2014, 35, 6143-6156. [CrossRef] [PubMed]

11. Koss, K.M.; Unsworth, L.D. Neural tissue engineering: Bioresponsive nanoscaffolds using engineered self-assembling peptides. Acta Biomater. 2016, 44, 2-15. [CrossRef] [PubMed]

12. Skop, N.B.; Calderon, F.; Cho, C.H.; Gandhi, C.D.; Levison, S.W. Improvements in biomaterial matrices for neural precursor cell transplantation. Mol. Cell. Ther. 2014, 2, 19. [CrossRef] [PubMed]

13. Tanaka, M.; Sato, Y.; Haniu, H.; Nomura, H.; Kobayashi, S.; Takanashi, S.; Okamoto, M.; Takizawa, T.; Aoki, K.; Usui, Y.; et al. A three-dimensional block structure consisting exclusively of carbon nanotubes serving as bone regeneration scaffold and as bone defect filler. PLoS ONE 2017, 12, e0172601. [CrossRef] [PubMed]

14. Perkins, B.L.; Naderi, N. Carbon nanostructures in bone tissue engineering. Open Orthop. J. 2016, 10, 877-899. [CrossRef] [PubMed]

15. Palejwala, A.H.; Fridley, J.S.; Mata, J.A.; Samuel, E.L.G.; Luerssen, T.G.; Perlaky, L.; Kent, T.A.; Tour, J.M.; Jea, A. Biocompatibility of reduced graphene oxide nanoscaffolds following acute spinal cord injury in rats. Surg. Neurol. Int. 2016, 7, 75. [CrossRef] [PubMed]

16. Kohane, D.S.; Langer, R. Polymeric biomaterials in tissue engineering. Pediatr. Res. 2008, 63, 487-491. [CrossRef] [PubMed]

17. Chen, G.; Ushida, T.; Tateishi, T. Scaffold design for tissue engineering. Macromol. Biosci. 2002, 2, 67-77. [CrossRef] 
18. Fukunishi, T.; Shoji, T.; Shinoka, T. Nanofiber composites in vascular tissue engineering. In Nanofiber Composites for Biomedical Applications; Woodhead Publishing: Cambridge, UK, 2017; pp. 455-481. ISBN 9780081001738.

19. Alvarez-Perez, M.A.; Guarino, V.; Cirillo, V.; Ambrosio, L. Influence of gelatin cues in PCL electrospun membranes on nerve outgrowth. Biomacromolecules 2010, 11, 2238-2246. [CrossRef] [PubMed]

20. Zhang, Z.; Xu, R.; Wang, Z.; Dong, M.; Cui, B.; Chen, M. Visible-Light neural stimulation on graphitic-carbon nitride/graphene photocatalytic fibers. ACS Appl. Mater. Interfaces 2017, 9, 34736-34743. [CrossRef] [PubMed]

21. Hemshekhar, M.; Thushara, R.M.; Chandranayaka, S.; Sherman, L.S.; Kemparaju, K.; Girish, K.S. Emerging roles of hyaluronic acid bioscaffolds in tissue engineering and regenerative medicine. Int. J. Biol. Macromol. 2016, 86, 917-928. [CrossRef] [PubMed]

22. Butterfield, K.C.; Conovaloff, A.W.; Panitch, A. Development of affinity-based delivery of NGF from a chondroitin sulfate biomaterial. Biomatter 2011, 1, 174-181. [CrossRef] [PubMed]

23. Weyers, A.; Linhardt, R.J. Neoproteoglycans in tissue engineering. FEBS J. 2013, 280, 2511-2522. [CrossRef] [PubMed]

24. Lei, J.; Yuan, Y.; Lyu, Z.; Wang, M.; Liu, Q.; Wang, H.; Yuan, L.; Chen, H. Deciphering the role of sulfonated unit in heparin-mimicking polymer to promote neural differentiation of embryonic stem cells. ACS Appl. Mater. Interfaces 2017, 9, 28209-28221. [CrossRef] [PubMed]

25. Zhou, K.; Thouas, G.A.; Bernard, C.C.; Nisbet, D.R.; Finkelstein, D.I.; Li, D.; Forsythe, J.S. Method to impart electro- and biofunctionality to neural scaffolds using graphene-polyelectrolyte multilayers. ACS Appl. Mater. Interfaces 2012, 4, 4524-4531. [CrossRef] [PubMed]

26. Cao, Z.; Gilbert, R.J.; He, W. Simple agarose-chitosan gel composite system for enhanced neuronal growth in three dimensions. Biomacromolecules 2009, 10, 2954-2959. [CrossRef] [PubMed]

27. Entekhabi, E.; Haghbin Nazarpak, M.; Moztarzadeh, F.; Sadeghi, A. Design and manufacture of neural tissue engineering scaffolds using hyaluronic acid and polycaprolactone nanofibers with controlled porosity. Mater. Sci. Eng. C 2016, 69, 380-387. [CrossRef] [PubMed]

28. Rad-Malekshahi, M.; Lempsink, L.; Amidi, M.; Hennink, W.E.; Mastrobattista, E. Biomedical Applications of Self-Assembling Peptides. Bioconjug. Chem. 2016, 27, 3-18. [CrossRef] [PubMed]

29. Mazza, M.; Hadjidemetriou, M.; De Lázaro, I.; Bussy, C.; Kostarelos, K. Peptide nanofiber complexes with siRNA for deep brain gene silencing by stereotactic neurosurgery. ACS Nano 2015, 9, 1137-1149. [CrossRef] [PubMed]

30. Stephanopoulos, N.; Freeman, R.; North, H.A.; Sur, S.; Jeong, S.J.; Tantakitti, F.; Kessler, J.A.; Stupp, S.I. Bioactive DNA-peptide nanotubes enhance the differentiation of neural stem cells into neurons. Nano Lett. 2015, 15, 603-609. [CrossRef] [PubMed]

31. Ellis-Behnke, R.G.; Liang, Y.-X.; You, S.-W.; Tay, D.K.C.; Zhang, S.; So, K.-F.; Schneider, G.E. Nano neuro knitting: peptide nanofiber scaffold for brain repair and axon regeneration with functional return of vision. Proc. Natl. Acad. Sci. USA 2006, 103, 5054-5059. [CrossRef] [PubMed]

32. Sur, S.; Pashuck, E.T.; Guler, M.O.; Ito, M.; Stupp, S.I.; Launey, T. A hybrid nanofiber matrix to control the survival and maturation of brain neurons. Biomaterials 2012, 33, 545-555. [CrossRef] [PubMed]

33. Hutton, J.C.; Schofield, P.J.; Williams, J.F.; Hollows, F.C. The failure of aldose reductase inhibitor $3,3^{\prime}$-tetramethylene glutaric acid to inhibit in vivo sorbitol accumulation in lens and retina in diabetes. Biochem. Pharmacol. 1974, 23, 2991-2998. [CrossRef]

34. Rosenberyg, D.; Artoul, S.; Segal, A.C.; Kolodney, G.; Radzishevsky, I.; Dikpoltsev, E.; Foltyn, V.N.; Inoue, R.; Mori, H.; Billard, J.-M.; et al. Neuronal D-Serine and Glycine Release Via the Asc-1 Transporter Regulates NMDA Receptor-Dependent Synaptic Activity. J. Neurosci. 2013, 33, 3533-3544. [CrossRef] [PubMed]

35. Arulmoli, J.; Pathak, M.M.; McDonnell, L.P.; Nourse, J.L.; Tombola, F.; Earthman, J.C.; Flanagan, L.A. Static stretch affects neural stem cell differentiation in an extracellular matrix-dependent manner. Sci. Rep. 2015, 5, 8499. [CrossRef] [PubMed]

36. Joo, S.; Yeon Kim, J.; Lee, E.; Hong, N.; Sun, W.; Nam, Y. Effects of ECM protein micropatterns on the migration and differentiation of adult neural stem cells. Sci. Rep. 2015, 5, 13043. [CrossRef] [PubMed]

37. Junka, R.; Valmikinathan, C.M.; Kalyon, D.M.; Yu, X. Laminin functionalized biomimetic nanofibers for nerve tissue engineering. J. Biomater. Tissue Eng. 2013, 3, 494-502. [CrossRef] [PubMed]

38. Tate, C.C.; Shear, D.A.; Tate, M.C.; Archer, D.R.; Stein, D.G.; LaPlaca, M.C. Laminin and fibronectin scaffolds enhance neural stem cell transplantation into the injured brain. J. Tissue Eng. Regen. Med. 2009, 3, $208-217$. [CrossRef] [PubMed] 
39. Baloh, R.H.; Tansey, M.G.; Lampe, P.A.; Fahrner, T.J.; Enomoto, H.; Simburger, K.S.; Leitner, M.L.; Araki, T.; Johnson, E.M.; Milbrandt, J. Artemin, a novel member of the GDNF ligand family, supports peripheral and central neurons and signals through the GFR $\alpha 3-R E T$ receptor complex. Neuron 1998, 21, 1291-1302. [CrossRef]

40. Detloff, M.R.; Smith, E.J.; Quiros Molina, D.; Ganzer, P.D.; Houlé, J.D. Acute exercise prevents the development of neuropathic pain and the sprouting of non-peptidergic (GDNF- and artemin-responsive) c-fibers after spinal cord injury. Exp. Neurol. 2014, 255, 38-48. [CrossRef] [PubMed]

41. Allen, S.J.; Watson, J.J.; Shoemark, D.K.; Barua, N.U.; Patel, N.K. GDNF, NGF and BDNF as therapeutic options for neurodegeneration. Pharmacol. Ther. 2013, 138, 155-175. [CrossRef] [PubMed]

42. Timpl, R.; Wiedmann, H.; van Delden, V.; Furthmayr, H.; Kúhn, K. A network model for the organization of type IV collagen molecules in basement membranes. Eur. J. Biochem. 1981, 120, 203-211. [CrossRef] [PubMed]

43. Boeva, Z.A.; Sergeyev, V.G. Polyaniline: Synthesis, properties and application. Polym. Sci. Ser. C 2014, 56, 144-153. [CrossRef]

44. Magnuson, M.; Guo, J.-H.; Butorin, S.M.; Agui, A.; Sathe, C.; Nordgren, J. The electronic structure of polyaniline and doped phases studied by soft X-ray absorption and emission spectroscopies. J. Chem. Phys. 1999, 111, 4756-4763. [CrossRef]

45. Li, M.; Guo, Y.; Wei, Y.; MacDiarmid, A.G.; Lelkes, P.I. Electrospinning polyaniline-contained gelatin nanofibers for tissue engineering applications. Biomaterials 2006, 27, 2705-2715. [CrossRef] [PubMed]

46. He, Q.; Shi, J.; Zhu, M.; Chen, Y.; Chen, F. The three-stage in vitro degradation behavior of mesoporous silica in simulated body fluid. Microporous Mesoporous Mater. 2010, 131, 314-320. [CrossRef]

47. Sun, L.; Zheng, C.; Webster, T.J. Self-assembled peptide nanomaterials for biomedical applications: Promises and pitfalls. Int. J. Nanomed. 2017, 73-86. [CrossRef] [PubMed]

48. Wan, S.; Borland, S.; Richardson, S.M.; Merry, C.L.R.; Saiani, A.; Gough, J.E. Self-assembling peptide hydrogel for intervertebral disc tissue engineering. Acta Biomater. 2016, 46, 29-40. [CrossRef] [PubMed]

49. Kogiso, M.; Ohnishi, S.; Yase, K.; Masuda, M.; Shimizu, T. Dicarboxylic oligopeptide bolaamphiphiles: Proton-triggered self-assembly of microtubes with loose solid surfaces. Langmuir 1998, 14, 4978-4986. [CrossRef]

50. Menzenski, M.Z.; Banerjee, I.A. Self-assembly of supramolecular nanostructures from phenylalanine derived bolaamphiphiles. New J. Chem. 2007, 31, 1674. [CrossRef]

51. Cote, Y.; Fu, I.W.; Dobson, E.T.; Goldberger, J.E.; Nguyen, H.D.; Shen, J.K. Mechanism of the pH-controlled self-assembly of nanofibers from peptide amphiphiles. J. Phys. Chem. C 2014, 118, 16272-16278. [CrossRef] [PubMed]

52. Matsui, H.; Gologan, B. Crystalline glycylglycine bolaamphiphile tubules and their pH-sensitive structural transformation. J. Phys. Chem. B 2000, 104, 3383-3386. [CrossRef]

53. Loo, Y.; Zhang, S.; Hauser, C.A.E. From short peptides to nanofibers to macromolecular assemblies in biomedicine. Biotechnol. Adv. 2012, 30, 593-603. [CrossRef] [PubMed]

54. Cuvier, A.-S.; Berton, J.; Stevens, C.V.; Fadda, G.C.; Babonneau, F.; Van Bogaert, I.N.A.; Soetaert, W.; Pehau-Arnaudet, G.; Baccile, N. pH-triggered formation of nanoribbons from yeast-derived glycolipid biosurfactants. Soft Matter 2014, 10, 3950-3959. [CrossRef] [PubMed]

55. Macdonald, P.R.; Lustig, A.; Steinmetz, M.O.; Kammerer, R.A. Laminin chain assembly is regulated by specific coiled-coil interactions. J. Struct. Biol. 2010, 170, 398-405. [CrossRef] [PubMed]

56. Hussain, S.-A.; Carafoli, F.; Hohenester, E. Determinants of laminin polymerization revealed by the structure of the $\alpha 5$ chain amino-terminal region. EMBO Rep. 2011, 12, 276-282. [CrossRef] [PubMed]

57. De Graaf, J.; Amons, R.; Möller, W. The primary structure of artemin from Artemia cysts. Eur. J. Biochem. 1990, 193, 737-741. [CrossRef] [PubMed]

58. Hassani, L.; Sajedi, R.H. Effect of artemin on structural transition of lactoglobulin. Spectrochim. Acta A Mol. Biomol. Spectrosc. 2013, 105, 24-28. [CrossRef] [PubMed]

59. Liu, G.Y.; Agarwal, R.; Ko, K.R.; Ruthven, M.; Sarhan, H.T.; Frampton, J.P. Templated assembly of collagen fibers directs cell growth in 2D and 3D. Sci. Rep. 2017, 7, 9628. [CrossRef] [PubMed]

60. Huang, K.; Wan, M. Self-assembled polyaniline nanostructures with photoisomerization function. Chem. Mater. 2002, 14, 3486-3492. [CrossRef]

61. Kong, J.; Yu, S. Fourier transform infrared spectroscopic analysis of protein secondary structures. Acta Biochim. Biophys. Sin. (Shanghai) 2007, 39, 549-559. [CrossRef] [PubMed] 
62. Almlén, A.; Vandenbussche, G.; Linderholm, B.; Haegerstrand-Björkman, M.; Johansson, J.; Curstedt, T. Alterations of the C-terminal end do not affect in vitro or in vivo activity of surfactant protein $\mathrm{C}$ analogs. Biochim. Biophys. Acta. Biomembr. 2012, 1818, 27-32. [CrossRef] [PubMed]

63. Langham, A.A.; Waring, A.J.; Kaznessis, Y.N. Comparison of interactions between beta-hairpin decapeptides and SDS/DPC micelles from experimental and simulation data. BMC Biochem. 2007, 8, 11. [CrossRef] [PubMed]

64. Baker, B.R.; Garrell, R.L. g-Factor analysis of protein secondary structure in solutions and thin films. Faraday Discuss. 2004, 126, 209. [CrossRef] [PubMed]

65. Wen, X.; Wang, Y.; Guo, Z.; Meng, H.; Huang, J.; Zhang, L.; Zhao, B.; Zhao, Q.; Zheng, Y.; Peng, J. Cauda equina-derived extracellular matrix for fabrication of nanostructured hybrid scaffolds applied to neural tissue engineering. Tissue Eng. Part A 2015, 21, 1095-1105. [CrossRef] [PubMed]

66. Vass, E.; Hollósi, M.; Besson, F.; Buchet, R. Vibrational spectroscopic detection of beta- and gamma-turns in synthetic and natural peptides and proteins. Chem. Rev. 2003, 103, 1917-1954. [CrossRef] [PubMed]

67. Pud, A.A.; Nikolayeva, O.A.; Vretik, L.O.; Noskov, Y.V.; Ogurtsov, N.A.; Kruglyak, O.S.; Fedorenko, E.A. New nanocomposites of polystyrene with polyaniline doped with lauryl sulfuric acid. Nanoscale Res. Lett. 2017, 12, 493. [CrossRef] [PubMed]

68. Arruebo, M.; Valladares, M.; Gonzalez-Fernandez, A. Antibody conjugated nanoparticles for biomedical applications. J. Nanomaterials 2009, 2009, 37. [CrossRef]

69. Gröschel, A.H.; Müller, A.H.E. Self-assembly concepts for multicompartment nanostructures. Nanoscale 2015, 7, 11841-11876. [CrossRef] [PubMed]

70. Heim, A.J.; Matthews, W.G.; Koob, T.J. Determination of the elastic modulus of native collagen fibrils via radial indentation. Appl. Phys. Lett. 2006, 89. [CrossRef]

71. Muiznieks, L.D.; Keeley, F.W. Molecular assembly and mechanical properties of the extracellular matrix: A fibrous protein perspective. Biochim. Biophys. Acta 2012, 1832, 866-875. [CrossRef] [PubMed]

72. Ding, J.; Li, X.; Wang, X.; Zhang, J.; Yu, D.; Qiu, B. Fabrication of vertical array CNTs/polyaniline composite membranes by microwave-assisted in situ polymerization. Nanoscale Res. Lett. 2015, 10, 493. [CrossRef] [PubMed]

73. Wei, Y.; Jang, G.W.; Hsueh, K.F.; Scherr, E.M.; MacDiarmid, A.G.; Epstein, A.J. Thermal transitions and mechanical properties of films of chemically prepared polyaniline. Polymer (Guildf) 1992, 33, 314-322. [CrossRef]

74. Xu, C.; Yang, F.; Wang, S.; Ramakrishna, S. In vitro study of human vascular endothelial cell function on materials with various surface roughness. J. Biomed. Mater. Res. A 2004, 71, 154-161. [CrossRef] [PubMed]

75. Chen, B.-Q.; Kankala, R.K.; Chen, A.-Z.; Yang, D.-Z.; Cheng, X.-X.; Jiang, N.-N.; Zhu, K.; Wang, S.-B. Investigation of silk fibroin nanoparticle-decorated poly(l-lactic acid) composite scaffolds for osteoblast growth and differentiation. Int. J. Nanomed. 2017, 12, 1877-1890. [CrossRef] [PubMed]

76. Nguyen, K.T.; West, J.L. Photopolymerizable hydrogels for tissue engineering applications. Biomaterials 2002, 23, 4307-4314. [CrossRef]

77. Sheikh, Z.; Najeeb, S.; Khurshid, Z.; Verma, V.; Rashid, H.; Glogauer, M. Biodegradable materials for bone repair and tissue engineering applications. Materials (Basel) 2015, 8, 5744-5794. [CrossRef] [PubMed]

78. Serbo, J.V.; Gerecht, S. Vascular tissue engineering: biodegradable scaffold platforms to promote angiogenesis. Stem Cell Res. Ther. 2013, 4, 8. [CrossRef] [PubMed]

79. Ikejima, T.; Inoue, Y. Crystallization behavior and environmental biodegradability of the blend films of poly(3-hydroxybutyric acid) with chitin and chitosan. Carbohydr. Polym. 2000, 41, 351-356. [CrossRef]

80. Bober, P.; Humpolíček, P.; Pacherník, J.; Stejskal, J.; Lindfors, T. Conducting polyaniline based cell culture substrate for embryonic stem cells and embryoid bodies. RSC Adv. 2015, 5, 50328-50335. [CrossRef]

81. Neal, R.A.; Lenz, S.M.; Wang, T.; Abebayehu, D.; Brooks, B.P.C.; Ogle, R.C.; Botchwey, E.A. Lamininand basement membranepolycaprolactone blend nanofibers as a scaffold for regenerative medicine. Nanomater. Environ. 2014, 2, 1-12. [CrossRef] [PubMed]

82. Wong, L.E.; Gibson, M.E.; Arnold, H.M.; Pepinsky, B.; Frank, E. Artemin promotes functional long-distance axonal regeneration to the brainstem after dorsal root crush. Proc. Natl. Acad. Sci. USA 2015, 112, 6170-6175. [CrossRef] [PubMed]

83. Önger, M.E.; Delibaş, B.; Türkmen, A.P.; Erener, E.; Altunkaynak, B.Z.; Kaplan, S. The role of growth factors in nerve regeneration. Drug Discov. Ther. 2016, 3, 285-291. [CrossRef] [PubMed] 
84. Shin, Y.J.; Kim, S.H.; Yang, D.H.; Kwon, H.; Shin, J.S. Amperometric glucose biosensor by means of electrostatic layer-by-layer adsorption onto polyaniline-coated polyester films. J. Ind. Eng. Chem. 2010, 16, 380-384. [CrossRef]

85. Ku, S.H.; Lee, S.H.; Park, C.B. Synergic effects of nanofiber alignment and electroactivity on myoblast differentiation. Biomaterials 2012, 33, 6098-6104. [CrossRef] [PubMed]

86. Gajendran, P.; Saraswathi, R. Polyaniline-carbon nanotube composites. Pure Appl. Chem. 2008, 80, $2377-2395$. [CrossRef]

(c)

(C) 2018 by the authors. Licensee MDPI, Basel, Switzerland. This article is an open access article distributed under the terms and conditions of the Creative Commons Attribution (CC BY) license (http://creativecommons.org/licenses/by/4.0/). 